\title{
THE COMMUNIST INTERNATIONAL, I9I9-43: THE PERSONNEL OF ITS HIGHEST BODIES
}

This survey of the personnel of the highest bodies of the Comintern is meant to be a tool for researchers and historians studying the history of the international labour movement, especially of the Communist International.

So far five contributions of direct relevance to this subject have appeared. First, the book by B. Lazitch Les partis communistes d'Europe (Paris, 1955). However, Lazitch's data are incomplete, as he names only 140 of the circa 360 members and candidates who were elected to the highest bodies of the Comintern from 1919 till 1943 (I follow the terminology of the sources). Lazitch fails to mention those persons who were elected to the ECCI (Executive Committee of the Communist International) between the Congresses of the International, viz., at the plenary sessions of the ECCI. Moreover, he does not give his sources, or identify pseudonyms, no more does he mention first names or the countries from which the various people came and/or which they represented.

Second, in 1973 B. Lazitch (in collaboration with M. M. Drachkovitch) published Biographical Dictionary of the Comintern (Stanford, 1973). This study furnishes information about 718 people who were active in the Comintern, as elected members of its bodies, as representatives of national Communist parties, as members of the apparatus, as liaison officers, etc. The author has added a list of pseudonyms. Despite the advance in the research concerning the Comintern represented by this book, I want to make some remarks about it. To begin with, I think that in view of the heuristic gaps and difficulties hampering research in this field it is a mistake that the sources used for the biographies of separate personalities are not given. This renders a comparison of the facts described with formerly published material difficult. It also leads to errors and inaccuracies. The author himself is the worst victim of his method, for he invites criticism. Once again, Lazitch's data are incomplete: of the circa 360 elected members and candidates of the highest bodies of the Comintern about 60 are lacking, 
among them several members and candidates of the Presidium and the Political Secretariat. Still, this book is an important contribution to the research on the Comintern and I consider it as the basis for a more extensive biographical dictionary.

The third study that pays attention to the composition of the leading bodies of the Comintern is J. Degras, The Communist International 1919-1943: Documents (3 vols; Oxford, 1956-65). This too shows many shortcomings. Degras does not identify pseudonyms, nor does she give first names. She does not give details about her sources for the composition of the leading bodies, but only furnishes a general survey at the end of each volume of the material she has consulted. For the people elected to the Comintern bodies at various ECCI meetings, and for those elected at the Seventh Comintern Congress, she does not state the countries or the Communist parties they represented.

Finally, I want to mention two contributions on the subject published in Czechoslovakia: 1) A. Hrbatová and F. Svátek, "Přehled o složení nejvyššich orgánů Kominterny 1919-1943" (Survey of the composition of the highest bodies of the Comintern 1919-43), in: Př́ispévky k Déjinám KSC, VI (Prague, 1966), pp. 878-943;2) F. Svátek, "The Governing Organs of the Communist International: their growth and composition, 1919-1943", in: History of Socialism Year Book 1968 (Prague, 1969), pp. 179-266.

These two contributions were published by the Institute of the History of the Communist Party of Czechoslovakia. Its director at the time, Professor Pavel Reiman, candidate to the ECCI in 1928-35 and to its Presidium in 1929-31, had worked for years in the apparatus of the Comintern. So it was to be expected that these studies would have contained fewer hiatuses and inaccuracies than they do. Thus, on p. 252 of the article by Svátek we find the name Tom without a first name and instead of the name of the country a question mark. But Tom was in fact Čeněk Hruška, member of the Politbureau of the CP of Czechoslovakia, who represented that CP on the ECCI in Moscow from 1933 to 1939, using the pseudonym Tom. Michal Wolf, member of the same CP from 1921 to 1940 , who, in the 1920 's, was sentenced to five and a half years' imprisonment because of illegal Communist activities in Czechoslovakia, is wrongly denoted as a member of the CP of Hungary in 1935 by the same author. In both Czech contributions Weiss, who was elected to the ICC (International Control Commission) for Czechoslovakia instead of Karel Kreibich at the Sixth Congress in 1928, is mentioned without his first name. It is a pity that these Czech authors do not say anything about the identity of Weiss in a footnote, so that to this day it is unknown in Czechoslovakia who Weiss really was. I have given a few examples, but I 
could have quoted many more. In spite of this I am convinced that Svátek's "The Governing Organs of the Communist International" is an excellent study and so far the most complete about the composition of the highest bodies of the Comintern.

In comparison to the titles mentioned above the survey of the composition of the highest bodies of the Comintern $I$ have drawn up aims at greater completeness and accuracy. It goes without saying that I do not pretend to absolute perfection and completeness, for these cannot be attained without access to the relevant archives. I attach great importance to mentioning first names, to the arrangement according to countries and to the identification of pseudonyms.

\section{A. First names}

When first names are not mentioned, it is frequently impossible to identify persons. E.g., between the Second and the Third Congresses Wilhelm Koenen was elected to the Little Bureau of the ECCI (Presidium). At that time, however, his brother Bernard was one of the leaders of the KPD and also working on the apparatus of the ECCI. Another example: at the 11th ECCI plenum in 1931 Müller (no first name, no country) was elected. At that time, however, the KPD had among its leaders Oscar Müller, Herbert Müller, Georg Müller and Kurt Müller, and the Swiss CP Robert Müller, who also took part in the ECCI meetings during the 1930's. The man elected was Kurt Müller. The same is true for the name Popov. At the Third Congress Dimitar Popov was elected for Bulgaria. At the Seventh Congress Blagoj Popov was elected. In addition to these two Nikolaj Popov was active in the Comintern and headed the delegation of the CP of the Soviet Ukraine at the Seventh Congress. His address at that Congress was published with his photo in the Moscow Pravda in August 1935. Further, Stanke Dimitrov, member of the bureau-in-exile of the CP of Bulgaria and collaborator in the ECCI apparatus, used the pseudonym Popov in August 1935.

\section{$B$. Arranging the names by countries}

From such an arrangement it is possible to deduct changes in the evaluation of the revolutionary situation in various countries by the Comintern leaders. It also gives an insight into the interests of Russian foreign policy in different periods. Some examples will illustrate this.

When the plans of the Comintern and the KPD to seize power in Germany by means of an armed revolution failed in October 1923, the Comintern directed its efforts chiefly to Britain. At the Fifth Congress in 1924 Zinov'ev stated: 
"Politically, the most important section of the Communist International, at present, is not the German, nor the Russian, but the British Section. Here we are faced by remarkable situations: a Party of only three to four thousand members, wields far wider influence than would appear from these figures. For in Britain we are dealing with a different tradition. MacDonald's party is not much stronger than ours. [...] The tradition of a mass party is not known in England. [...] To form a mass party in England is the chief task of the entire present period. The conditions are there."1

As a result of this judgment of the situation the number of representatives of the CP of Great Britain, elected to bodies of the Comintern, was considerably larger after the Fifth Congress. Whereas at the Third Congress one ECCI member was elected and at the Fourth one ECCI member and one candidate, at the Fifth five people were elected to Comintern bodies. Of these five two were elected to the Presidium at the first session of the newly elected ECCI after the Congress. Moreover, MacManus became a member of the Orgbureau and a candidate to the ECCI Secretariat. Later the number became even larger.

Another example can be found in the shifts of the representation of the CP of China on the bodies of the Comintern after the well-known conflict of the united opposition with Stalin over the policy of Stalin and the Comintern towards China. Whereas from the First to the Fifth Congress China was either not represented at all on the bodies of the Comintern, or at most by one candidate, and after the Fifth Congress by one member on the ECCI, at the Sixth Congress six people were elected to bodies of the Comintern, while one of them was elected to the Presidium and the Political Secretariat of the ECCI as well. The changes in the interest attached to the CPs of Yugoslavia and Bulgaria by the Comintern can be seen from the numbers of representatives of these parties. Until the Seventh Congress in 1935 both parties were about equally represented. At the Seventh Congress there was a sudden change: of the four people proposed by the CP of Yugoslavia only Gorkic (Čižinski), the then secretary-general of that $\mathrm{CP}$, was elected as a candidate. On the other hand, five people proposed by the CP of Bulgaria were elected to fill nine functions, two of them on the Presidium. Georgi Dimitrov also became a member of the Political Secretariat of the ECCI and Secretary-General of the Comintern. At a later stage, in the years 1938-39, the ECCI Secretariat

1 Fifth Congress of the Communist International. Abridged Report of Meetings held at Moscow June 17th to July 8th, 1924 (London, n.d.), p. 35. 
deliberated extensively, if the CP of Yugoslavia should be dissolved. ${ }^{1}$

\section{Pseudonyms}

I am convinced that the identification of the pseudonyms of the Comintern officials will be useful to fill in the gaps still to be found in a series of political biographies of these people. It can also be useful for the study of the history of various national parties. Every one who has gone deeply into the history of the Comintern knows that the identification of pseudonyms is a very complicated problem, which has given rise to numerous polemics, some of them undecided even now. ${ }^{2}$

A fact that is less known, or at least less often mentioned, is that the use of pseudonyms in the Comintern was not solely a consequence of illegality, but also had a political function - especially for certain people. For example, at the Sixth Congress Knorin and Popov, both members of the CPSU, were elected under the pseudonyms Sokolik and Lovickij as ECCI candidates for the CP of Poland. Both of them played an important part in deposing the Kostrzewa-Warski group from the leadership of the CP of Poland later on. The same thing happened to Sakun, a member of the CPSU, who was elected as candidate to the ECCI Presidium for the CP of Yugoslavia under the pseudonym Milković, and played a similar part in the expulsion of Sima Marković, the then secretary-general, from the leadership of the CP of Yugoslavia. ${ }^{3}$

In some cases we find that not one but several Comintern functionaries acted under the same pseudonym at different periods, or, on the other hand, that the same person used different pseudonyms at the same time. During his work in Vienna in 1924 Georgi Dimitrov was known under the pseudonym Dimov among the members of the bureau-in-exile of the CP of Bulgaria, and among the leadership of the Balkan Communist Federation under the pseudonym Viktor, but at the same time he used the pseudonym Oswald as ECCI representative

1 In October 1939 Jan Sverma, then head of the bureau-in-exile of the CP of Czechoslovakia situated in Paris, and candidate to the ECCI, left for Yugoslavia, instructed by the ECCI Secretariat to investigate the situation in the leadership of the Yugoslav CP, which was to be dissolved in the same way as the CP of Poland. On his return to Moscow in the spring of 1940, Sverma gave an extensive report to the ECCI Secretariat about the situation in the Yugoslav $C P$, refuting all the accusations made and thus stopping the dissolution. These facts, known to me owing to my association with Sverma's family for many years, are confirmed by Milovan Djilas, Memoir of a Revolutionary (New York, 1973), pp. 341-42.

2 See J. Degras, The Communist International 1919-1943, II, p. 573.

3 See Tables 37 and 39, notes. 
for the CP of Austria. Another example is the pseudonym Ziegler. At one time this was used by Alfred Kurella, while at the fifth congress of the Czechoslovak CP in Prague in February 1929 the ECCI was represented by Henryk Henrykowski (Saul Amsterdam) under the same pseudonym. Under his own name Egidio Gennari was elected a member of the ICC at the Fifth Comintern Congress. At the 8th ECCI plenum he also got into the Presidium and the Political Secretariat of the ECCI under the pseudonym Maggi - taking the place of Ercoli (Togliatti). He kept these places till the Sixth Congress. ${ }^{1}$ It must be noted that by the latter elections of Gennari the statutes of the Comintern were broken, for members of the ICC were not allowed to sit on other bodies of the Comintern at the same time. ${ }^{2}$

The following survey has been arranged chronologically according to the Comintern Congresses. At each Congress an ECCI was elected, from the Fifth Congress an ICC too. Each newly elected ECCI then elected its executive bodies at its constituent meeting. In the course of the years the number and the names of these bodies changed.

The tables give the composition of the separate bodies, stating the source in each case; Nos 34, 35, 41, 42, 45-48 and 53-56 are my own account. Within the separate bodies the names are listed by countries. I put the USSR first (till the Fourth Congress: Russia and the other republics, the latter in alphabetical order; till the Sixth Congress: USSR and Ukrainian SSR) in view of her extraordinary part in the activities of the Comintern and because Moscow was the only and permanent seat of the Comintern. All the other countries are put in alphabetical order. Since in a number of cases the sources do not mention the countries for which people were elected to the bodies of the Comintern, I add these (with a few exceptions). This is true for the ECCI elected at the Fifth Congress; for the ECCI and ICC elected at the Seventh Congress; for the bodies of the ECCI (Presidium, Orgbureau, Secretariat, Political Secretariat) elected at the constituent meetings of the newly elected ECCIs after the Congresses; and for the

\footnotetext{
1 Within the framework of this article it is impossible to go into the reasons why precisely Gennari, under the pseudonym Maggi, was put in Ercoli's (Togliatti's) place in 1927 and why it was that Togliatti did not return to the Political Secretariat of the ECCI until the 11th ECCI plenum in April 1931.

${ }^{2}$ From the Fifth Congress the ICC was an independent body of the Comintern and was elected exclusively by the Congresses. One of its tasks was the investigation of complaints about the actions of various departments of the ECCI. Tätigkeitsbericht der Exekutive der Kommunistischen Internationale für die Zeit vom 5. bis zum 6 . Weltkongress. Die Komintern vor dem 6 . Weltkongress (Hamburg, 1928), p. 85.
} 
bodies of the ECCI elected at the enlarged ( 1 to 7 ) and non-enlarged (8 to 13) plenary sessions of the ECCI.

Within the countries the names are arranged alphabetically. In the publications quoted as sources no first names are mentioned. In so far as I was able to do so from the material at my disposal or from my own knowledge, I have added the first names. However, if this would not give rise to misunderstandings, I have done so only the first time a person appears; see also the Index of names on pp. 181ff. People who do not or not only represent their national parties are put at the end of the table, e.g., Kolarov, Vasil, for the Balkans, or Kun, personally.

For the members of bodies of the Comintern who were elected under a pseudonym, I put their real names within brackets the first time they are mentioned, in so far as I have been able to decipher their pseudonyms. When $I$ have not yet succeeded in deciphering the pseudonym, I have put (pseud.) after the name and, when I am not certain whether the name mentioned is a person's real name or a pseudonym, I have put (pseud.?). Brackets are used when additional information is added to a source, e.g., Zetkin (personally). When the accuracy of the additional information is doubtful a question mark is used, e.g., Lozovskij (for the RILU?).

\section{FIRST CONGRESS (2-6 MARCH 1919)}

\section{Table 1. The ECCI after the First Congress ${ }^{1}$}

Russia Zinov'ev, Grigorij E. (Radomysl'skij), Chairman; Balabanova, Anželika; Berzin, Jan A.; Bucharin, Nikolaj I. ; Karachan, Lev M.; Klinger, Gustav K.; Litvinov, Maksim M. (Finkelstein); Vorovskij, Vaclav V.; and others

$\begin{array}{llll}\text { Finland } & \text { Sirola, Yrjö } & \text { Poland } & \text { Marchlewski, Julian } \\ \text { Latvia } & \text { Stučka, Petr } & \text { Yugoslavia } & \text { Milkić, Ilija }\end{array}$

The Secretaries of the ECCI were successively:

Russia Balabanova; Vorovskij; Berzin; Radek, Karl (Sobelsohn)

Source: G. Zinov'ev, Report of the Executive Committee of the Communist International (Petrograd, 1920), pp. 4-5²

\footnotetext{
'At the First Congress mainly questions pertaining to the programme of the Comintern were dealt with. As to the structure of the new institution, only the ECCI was elected as an executive body. The Congress directed the ECCI to elect from its ranks a Bureau of five members. The first task of this Bureau (after the Second Congress it was called the Little Bureau) was to conduct the illegal work of the separate Communist parties. A more penetrating study about the development of the structure of the Comintern bodies and their apparatus is in preparation.

2 F. I. Firsov gives a slightly different list; Sirola does not appear as a member of the ECCI, but A. Men'soj and E. Rudnyánszky do. See Vtoroj Kongress Kominterna. Razrabotka kongressom idejnych, taktičeskich $\mathbf{i}$ organizacionnych osnov kommunističeskich partij (Moscow, 1972), p. 51. (From the First until the Second Congress A. G. Men'šoj (L. S. Levin) under the pseudonym
} 
SECOND CONGRESS (19 JULY - 7 AUGUST 1920)

\section{Table 2. The ECCI elected after the Second Congress}

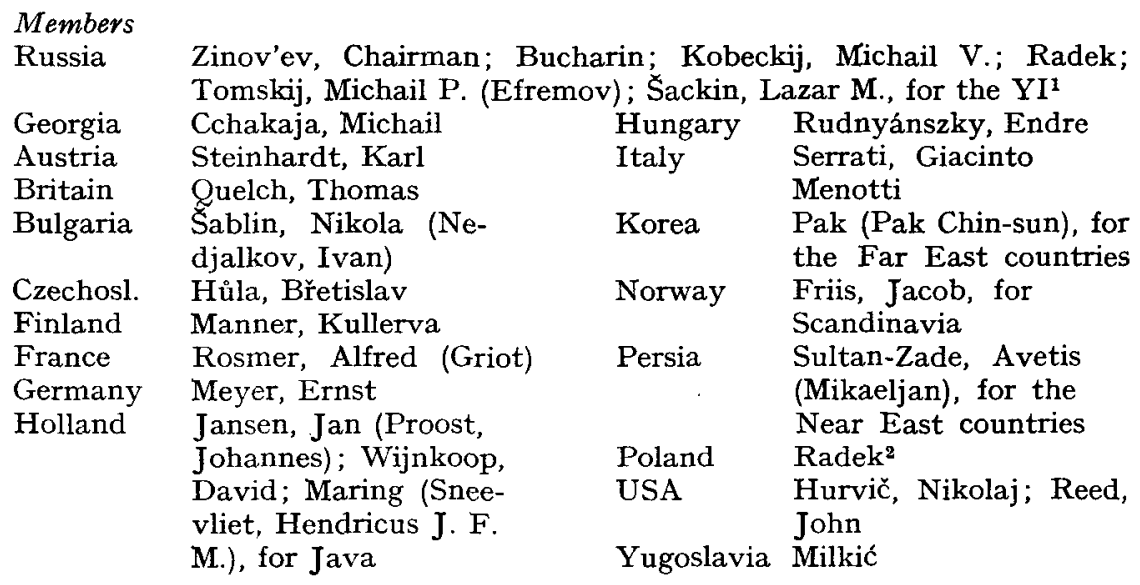

Candidates

Russia Berzin; Ciperovič, Grigorij V.; Lenin, Vladimir I. (Ul'janov); Pavlovič (Vel'tmann, Michail L.); ${ }^{3}$ Stalin, Iosif V. (Džugašvili); Trockij, Lev D. (Bronstein)

Germany Levi, Paul Latvia Stučka

Italy Cesare (Sessa, Cesare?)

Source: 10 Let Kominterna v rešenijach i cifrach. Sostaviteli A. Tivel' i M. Chejmo (Moscow, Leningrad, 1929), p. 494

Table 3. The Little Bureau of the ECCI elected after the Second Congress

Russia Zinov'ev, Chairman; Bucharin; Kobeckij

Germany Meyer Hungary Rudnyánszky

Source: 10 Let Kominterna, p. 293

Gaj headed the press department of the ECCI, see V. I. Lenin i VCK (Moscow, 1975), p. 409.) In 1935, in an interview with B. I. Nikolaevskij in Prague, Thomas (Jakub Reich), head of the West European Secretariat of the ECCI in Berlin from 1919 until 1925, gave the composition of the ECCl and its Bureau after the First Congress as follows. ECCI: Zinov'ev; Bucharin; Lenin; Rakovskij; Thomas; Vorovskij, Secretary; Bureau: Zinov'ev, Chairman; Bucharin; Carlo (Ljubarskij); Klinger, Administrative Secretary; Thomas; Vorovskij, Secretary; Berzin, his deputy. B. I. Nikolaevskij, "Na zare Kominterna. Rasskaz 'tovarišca Tomasa'”, in: Socialističeskij Vestnik, Sbornik No 1 (New York, 1964), p. 132.

1 Youth International, from 1922 Communist Youth International, CYI, or Youth Communist International, YCI.

2 Radek was elected twice, first as a member of the $\mathrm{RCP}(\mathrm{B})$, secondly as a member of the Polish CP.

3 Pavlovič (Vel'tmann) became known as Volonter.

- Pravda (Moscow), 10 August 1920, omits Hủla, Meyer, Jansen, Maring and Hurvič as members, and Ciperovic, Cesare and Stučka as candidates; it mentions Levi as a member, and Cičerin, Jansen, Meyer and Varga as candidates, 


\section{Table 4. The Little Bureau before the Third Congress}

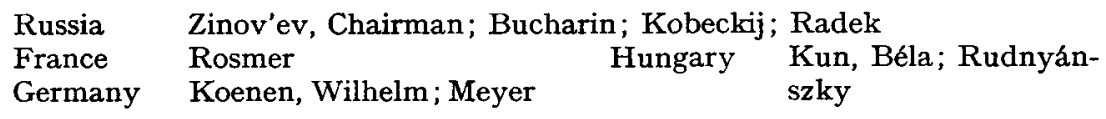

Source: ibid.

$$
\text { THIRD CONGRESS (22 JUNE - } 12 \text { JULY 1921) }
$$

\section{Table 5. The ECCI elected after the Third Congress}

\begin{tabular}{|c|c|c|c|}
\hline Ru: & Zinov'ev, Chairman: Bu & arin. Le & adek - Trock \\
\hline Ukraine & ii Aleksandr Ia. & $\mathrm{Hu}$ & anos, for the \\
\hline Austria & Koritschoner, Franz & Italy & Terracini, Umberto \\
\hline Belgium & $\begin{array}{l}\text { Overstraeten, Edward } \\
\text { van }\end{array}$ & $\begin{array}{l}\text { Latvia } \\
\text { Norway }\end{array}$ & $\begin{array}{l}\text { Stučka } \\
\text { Scheflo, Olaf }\end{array}$ \\
\hline Britain & Bell, Thomas & Poland & Gliński, Piotr (Króli- \\
\hline $\begin{array}{l}\text { Bulgaria } \\
\text { Czechosl. }\end{array}$ & $\begin{array}{l}\text { Popov, Dimitar } \\
\text { Burian, Edmund; Krei- } \\
\text { bich, Karel }\end{array}$ & Rumania & $\begin{array}{l}\text { kowski, Stefan) } \\
\text { Badulescu (Moscovici, } \\
\text { Gelbert) }\end{array}$ \\
\hline Finland & Sirola & Spain & Merino-Gracia, Ramón \\
\hline Fran & $\begin{array}{l}\text { Souvarine, Boris (Lifšis, } \\
\text { Boris) }\end{array}$ & $\begin{array}{l}\text { Sweden } \\
\text { Switzerland }\end{array}$ & $\begin{array}{l}\text { Kilbom, Karl } \\
\text { Arnold, Emil }\end{array}$ \\
\hline Germany & $\begin{array}{l}\text { Frölich, Paul; Heckert, } \\
\text { Fritz; Münzenberg, }\end{array}$ & & $\begin{array}{l}\text { Baldwin (Tywerousky, } \\
\text { Oscar) }\end{array}$ \\
\hline Holland & $\begin{array}{l}\text { Willi, for the YI } \\
\text { Jansen }\end{array}$ & Yugoslavia & ović, Sima \\
\hline an & & & \\
\hline Russia & Kamenev, Lev B. (Rose & d, Lev B.); Ko & obeckij \\
\hline Armenia & $\begin{array}{l}\text { Kasjan, Sarkis (Ter- } \\
\text { Kasparjan, Sarkis) }\end{array}$ & $\begin{array}{l}\text { Korea } \\
\text { Lithuania }\end{array}$ & $\begin{array}{l}\text { Ham Man-chen } \\
\text { Angaretis, Zigmas }\end{array}$ \\
\hline Azerbaijan & Musabekov, Gazan-Far & & Aleksa \\
\hline Georgia & Cchakaja & Mexico & Roy, Manabendra \\
\hline Australia & Freeman, Paul & & (Bhattacharya, Nanedra \\
\hline China & Chan-Kai (pseud.) & & Nath) ${ }^{1}$ \\
\hline Denmark & Jörgensen, Aage & Palestine & Sar (pseud.) \\
\hline Estonia & Pögelmann, Hans & Persia & Sultan-Zade \\
\hline Greece & Dimitratos(, Panagis?) & South Africa & Jones, David Yvon \\
\hline
\end{tabular}

Source: Die Tätigkeit der Exekutive und des Präsidiums des E.K. der Kommunistischen Internationale vom 13. Juli 1921 bis 1. Februar 1922 (Petrograd, 1922), pp. 5-6

10 Let Kominterna, p. 307, gives Roy for India, not for Mexico. 
Table 6. The Little Bureau elected after the Third Congress (13 July 1921)

Russia Zinov'ev, Chairman; Bucharin; Radek

France Souvarine Hungary

Germany Heckert

Kun

Gennari, Egidio

Source: Die Tätigkeit, op. cit., p. 7

Table 7. The Secretariat of the ECCI elected after the Third Congress (13 July 1921)

Finland Kuusinen, Otto W. Switzerland Humbert-Droz, Jules

Hungary Rákosi, Mátyás

Source: ibid.

Table 8. The ICC elected after the Third Congress (13 July 1921)

Finland Sirola

France Vaillant-Couturier,

Germany Zetkin, Clara, Chair-

Paul; Ker, Antoine man; Koenen, Wilhelm

(Keim, Louis Antoine),

Poland Walecki, Henryk

his deputy

(Horwitz, Maksymilian)

Source: Die Tätigkeit, op. cit., p. 16

Table 9. The Presidium of the ECCI elected after the 1st enlarged plenum (24 January - 4 March 1922) $^{1}$

Members

Russia

Czechosl.

Zinov'ev, President; Bucharin; Radek

France

Kreibich

Italy

Terracini

varine $^{2}$

USA

Carr, James (Kat-

terfeld, Ludwig)

Germany Brandler, Heinrich

Candidates

Finland

Kuusinen

Poland

Walecki

Source: Die Taktik der Kommunistischen Internationale gegen die Offensive des Kapitals. Bericht iiber die Konferenz der Erweiterten Exekutive der Kommunistischen Internationale, Moskau, vom 24. Februar bis 4. März 1922 (Hamburg, 1922), p. 144

Table 10. The Secretariat of the ECCI elected by the Presidium on 17
March 1922

Finland Kuusinen, Secretary- Hungary Rákosi General

Germany Eberlein, Hugo

Source: Bericht über die Tätigkeit des Präsidiums und der Exekutive der Kommunistischen Internationale für die Zeit vom 6. März bis 11. Juni 1922 (Hamburg, 1922), p. 8

${ }^{1}$ At the close of its session of 26 August 1921, the Little Bureau was abolished and converted in to the Presidium of the ECCI. See Die Tätigkeit, op. cit., p. 142.

2 Sellier and Souvarine had a joint vote in the ECCI. See Die Tätigkeit, p. 143. 
Table 11. The Secretariat of the ECCI before the 2nd enlarged plenum

Russia Kon, Feliks Ja. Germany Eberlein

Finland Kuusinen Hungary Rákosi

Source: Bericht ïber die Tätigkeit des Präsidiums und der Exekutive, pp. 8, 30

Table 12. The Presidium of the ECCI elected at the 2nd enlarged plenum (7-11 June 1922)

\begin{tabular}{|c|c|c|c|}
\hline \multicolumn{4}{|l|}{ Members } \\
\hline Bulgaria & Jordanov, Jordan & France & Leiciague, Lucie; \\
\hline Czechosl. & Jilek, Bohumil; Smeral, & & Souvarine ${ }^{2}$ \\
\hline & Bohumír ${ }^{1}$ & Italy & Gramsci, Antonio \\
\hline Cand & & & \\
\hline Finlan & Kuusinen & USA & $\begin{array}{l}\text { Cook, James (Cannon, } \\
\text { James P.) }\end{array}$ \\
\hline
\end{tabular}

Source: Inprekorr, Vol. 2, p. 716 (17 June 1922)

\section{Table 13. The ECCI before the Fourth Congress}

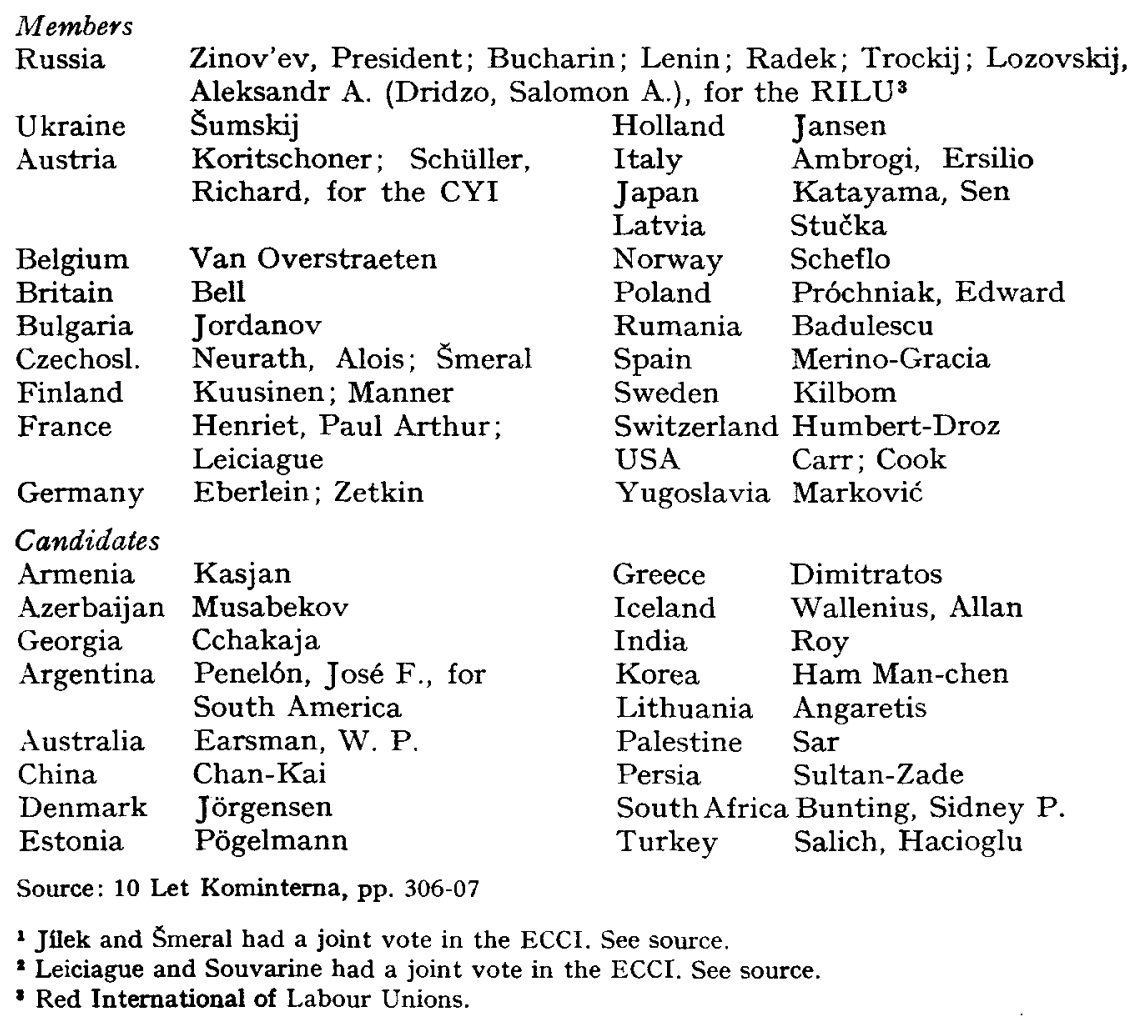


Table 14. The Presidium of the ECCI at the time of the Fourth Congress

Russia Zinov'ev, President; Bucharin; Radek; Sackin (for the CYI)

Bulgaria Jordanov Germany Brandler

Finland Kuusinen Italy Ambrogi

France Souvarine USA Carr

Source: 10 Let Kominterna, p. $307^{1}$

Table 15. The Secretariat of the ECCI at the time of the Fourth Congress

$\begin{array}{llll}\text { Russia } & \text { Kon; Minkin, Aleksandr } & \text { Germany } & \text { Eberlein } \\ & \text { E. } & \text { Hungary } & \text { Rákosi } \\ \text { Finland } & \text { Kuusinen } & & \end{array}$

Source: ibid.

\section{FOURTH CONGRESS (5 NOVEMBER - 5 DECEMBER 1922)}

\section{Table 16. The ECCI elected at the Fourth Congress}

\begin{tabular}{|c|c|c|c|}
\hline $\begin{array}{l}\text { Members } \\
\text { Russia }\end{array}$ & $\begin{array}{l}\text { Zinov'ev, President; Bu } \\
\text { Safarov, Georgij I. (Egor }\end{array}$ & $\begin{array}{l}\text { rin; Ra } \\
\text { Georgij I }\end{array}$ & $\begin{array}{l}\text { Sackin, for the CYI; } \\
\text { or the Eastern countries }\end{array}$ \\
\hline Australia & Garden, John S. & Japan & Katayama, for the \\
\hline Austria & Schüller, for the CYI & & Eastern countries \\
\hline Britain & MacManus, Arthur & Mexico & Stirner, Alfred (Woog, \\
\hline Bulgaria & $\begin{array}{l}\text { Kolarov, Vasil, for the } \\
\text { Balkans }\end{array}$ & & $\begin{array}{l}\text { Edgar), for South } \\
\text { America }\end{array}$ \\
\hline Czechosl. & Neurath; Smeral & Norway & Scheflo, for Scandinavia \\
\hline Finland & Kuusinen & Poland & Próchniak \\
\hline France & $\begin{array}{l}\text { Frossard, Ludvic Oscar; } \\
\text { Souvarine }\end{array}$ & $\begin{array}{l}\text { South Afri } \\
\text { Sweden }\end{array}$ & $\begin{array}{l}\text { Andrews, William } \mathbf{H} \text {. } \\
\text { Höglund, Karl Zeth, for }\end{array}$ \\
\hline any & Hoernle, Edwin; Zetkin & Sweuten & Scandinavia \\
\hline Italy & Gennari; Gramsci & USA & Carr \\
\hline Candi & & & \\
\hline $\begin{array}{l}\text { Russia } \\
\text { Britain }\end{array}$ & $\begin{array}{l}\text { Lenin; Trockij } \\
\text { Newbold, J. T. Walton }\end{array}$ & India & $\begin{array}{l}\text { Roy, for the Eastern } \\
\text { countries }\end{array}$ \\
\hline Czechosl. & Muna, Alois & Italy & Bordiga, Amadeo \\
\hline France & $\begin{array}{l}\text { Duret, Jean (Koral, } \\
\text { François) }\end{array}$ & Rumania & $\begin{array}{l}\text { Macavei, Mihai, for the } \\
\text { Balkans }\end{array}$ \\
\hline Germany & Böttcher, Paul Herbert & USA & $\begin{array}{l}\text { Damon, David (Ruth- } \\
\text { enberg, Charles Emil) }\end{array}$ \\
\hline
\end{tabular}

Source: Protokoll des Vierten Kongresses der Kommunistischen Internationale. PetrogradMoskau vom 5. November bis 5. Dezember 1922 (Hamburg, 1923), p. 967

\section{Table 17. The Presidium of the ECCI elected at the plenary session after the Fourth Congress}

\section{Members}

Russia Zinov'ev, President; Bucharin; Radek

1 This source does not mention Šmeral as a member of the Presidium. 


\begin{tabular}{|c|c|c|c|}
\hline Britain & MacManus & France & Souvarine \\
\hline Bulgaria & Kolarov (for the & Germany & Zetkin \\
\hline & Balkans) & Italy & Gennari \\
\hline Czechosl. & Neurath & Japan & Katayama \\
\hline Finland & Kuusinen & & \\
\hline Candidates & & & \\
\hline Russia & $\begin{array}{l}\text { Safarov (for the East- } \\
\text { ern countries) }\end{array}$ & $\begin{array}{l}\text { France } \\
\text { Germany }\end{array}$ & $\begin{array}{l}\text { Lévy, Georges } \\
\text { Hoernle }\end{array}$ \\
\hline
\end{tabular}

Source: Bericht der Exekutive der Kommunistischen Internationale 15. Dezember 1922 15. Mai 1923 (Moscow, 1923), p. $80^{1}$

Table 18. The Secretariat of the ECCI elected at the plenary session after the Fourth Congress

\section{Members}

Russia Pjatnickij, Osip A. (Taršis, Iosif A.)

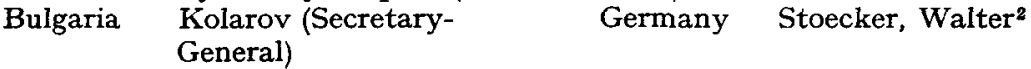

Candidates

Finland Kuusinen

Hungary Rákosi

Source: Bericht der Exekutive, op. cit., p. 7

Table 19. The Orgburean of the ECCI elected at the plenary session after the Fourth Congress

\section{Members}

Russia

Austria

Bulgaria

Pjatnickij; Safarov (for the Eastern countries)

Czechosl.

Schüller (for the CYI)

Kolarov

Neurath

$\begin{array}{ll}\text { Finland } & \text { Kuusinen } \\ \text { Germany } & \text { Hoernle } \\ \text { Hungary } & \text { Rákosi }\end{array}$

Candidates

Russia Vompe, Pavel A. ${ }^{3}$

Source: Bericht der Exekutive, op. cit., p. 80

Table 20. The Presidium of the ECCI elected at the 3rd enlarged plenum (12-23 June 1923)

$\begin{array}{llll}\text { Russia } & \text { Zinov'ev, President; Bucharin; Radek; Sackin (for the CYI) } \\ \text { Britain } & \text { MacManus } & \text { Czechosl. } & \text { Neurath } \\ \text { Bulgaria } & \text { Kolarov (for the } & \text { Finland } & \text { Kuusinen } \\ & \text { Balkans) } & \text { France } & \text { Souvarine }\end{array}$

110 Let Kominterna, p. 316, mentions Sackin and Smeral as members, Gramsci and Neurath as candidates; it omits Safarov and Lévy as candidates.

2 At the close of the plenum, Stoecker was replaced by Neurath (Czechoslovakia). See source.

2 Vompe headed the OMS (Section of International Communications) from its institution in 1921 until his death on 1 August 1925. The OMS was responsible for all secret activities of the Comintern. See Osip Pjatnickij, "Unsere Toten", in: Inprekorr, Vol. 5, pp. 1727-28 (11 August 1925). 
$\begin{array}{ll}\text { Germany } & \text { Zetkin } \\ \text { Italy } & \text { Terracini }\end{array}$

Japan Katayama (for the Eastern countries)

Scandinavia one representative

Source: Protokoll der Konferenz der Erweiterten Exekutive der Kommunistischen Internationale, Moskau, 12.-23. Juni 1923 (Hamburg, 1923), p. 321

\section{Table 21. The Secretariat of the ECCI elected at the 3rd enlarged plenum}

\section{Members}

Russia Pjatnickij

Bulgaria

Kolarov (Sec

General)

Czechosl. Neurath

Candidates

Finland Kuusinen

Hungary Rákosi

Poland Brand, Ernest (Lauer, Henryk)

Source: Inprekorr, Vol. 3, p. 1013 (9 July 1923)

\section{Table 22. The Orgbureau elected at the 3 rd enlarged plenum}

\section{Members}

Russia

Britain MacManus

Bulgaria

Kolarov (for the

Balkans)

Candidates

Britain Stewart, Robert

Source: 10 Let Kominterna, p. 316

$\begin{array}{ll}\text { Finland } & \text { Kuusinen } \\ \text { France } & \text { Souvarine } \\ \text { Italy } & \text { Terracini }\end{array}$

Italy $\quad$ Terracini

\section{FIFTH CONGRESS (16 JUNE - 8 JULY 1924)}

\section{Table 23. The ECCI elected at the Fifth Congress}

\section{Members}

USSR

UkrSSR

Argentina

Austria

Belgium

Britain

Bulgaria

Zinov'ev, President; Bucharin; Kamenev; Rykov, Aleksej I.; Stalin; Hessen, Sergej M. (for the CYI)

Frunze, Michail V.; Manuil'skij, Dimitrij $Z$.

Penelón (for Latin America)

Fiala, Gottlieb; Schüller (for the CYI)

Jacquemotte, Joseph

MacManus; Pollitt, Har-

ry

Kolarov
China Chen Tu-hsiu

Czechosl. Muna; Neurath; Smeral

Finland Kuusinen (for Finland and the Baltic states)

France Sellier; Sémard, Pierre; Treint, Albert

Germany Geschke, Ottomar; Rosenberg, Arthur;

Schlecht, Paul; Zetkin (personally)

${ }^{1} 10$ Let Kominterna, p. 316, mentions Smeral, Bordiga and Schüller instead of Neurath, Terracini and Sackin; it adds Neurath, Terracini and Stewart as candidates. 


\begin{tabular}{|c|c|c|c|}
\hline $\begin{array}{l}\text { Holland } \\
\text { India }\end{array}$ & $\begin{array}{l}\text { Wijnkoop } \\
\text { Roy }\end{array}$ & Spain & $\begin{array}{l}\text { Persolis (Pérez Solis, } \\
\text { Oscar) }\end{array}$ \\
\hline Italy & $\begin{array}{l}\text { Bordiga; Ercoli (To- } \\
\text { gliatti Palmiro) }\end{array}$ & $\begin{array}{l}\text { Sweden } \\
\text { USA }\end{array}$ & $\begin{array}{l}\text { Höglund; Kilbom } \\
\text { Foster, William Z. }\end{array}$ \\
\hline Japan & Katayama & & Ruthenberg, Charles \\
\hline Java & Semaoen & & Emil \\
\hline Norway & Scheflo & Yugoslavia & Filipović, Filip; \\
\hline Poland & $\begin{array}{l}\text { Grzegorzewski (Grzel- } \\
\text { szczak, Franciszek) }\end{array}$ & & $\begin{array}{l}\text { Kaclerović, Triša; } \\
\text { Vujović, Voja (for the }\end{array}$ \\
\hline Rumania & Cristescu, Gheorghe & & CYI) \\
\hline
\end{tabular}

Candidates

USSR Petrov (Raskol'nikov, Fedor F.);' Pjatnickij; Trockij; Lozovskij (for the RILU?)

Britain Gallacher, William;

Stewart

Bulgaria Dimitrov, Georgi

Czechosl. Dobrovolný, Filip;

Verčik, Július; Zá-

potocký, Antonín

\begin{tabular}{|c|c|}
\hline & Larkin, James \\
\hline Ital & $\begin{array}{l}\text { Maffi, Fabrizio; Rie } \\
\text { (Tasca, Angelo); } \\
\text { Scoccimarro, Maur }\end{array}$ \\
\hline ithuania & $\begin{array}{l}\text { Mickiewicz-Kapsuk } \\
\text { Vincas (for Finland } \\
\text { the Baltic states) }\end{array}$ \\
\hline O & , Arvid G. \\
\hline & $\begin{array}{l}\text { Bogucki, Waclaw; } \\
\text { Niedobytyj (Ladan } \\
\text { Pawel) }\end{array}$ \\
\hline & Samuelson, Oscar \\
\hline$S_{1}$ & $\begin{array}{l}\text { Dunne, William F. } \\
\text { Marković }\end{array}$ \\
\hline
\end{tabular}

Hungary Kun (personally) ${ }^{2}$

Doriot, Jacques;

Girault, Suzanne

(Depollier, Suzanne);

Jerram, Guy

Germany Fischer, Ruth (Eisler,

Elfriede); Maslow, Ar-

kadi (Cemerinskij, Isak);

Thälmann, Ernst

Source: Pjatyj Vsemirnyj Kongress Kommunističeskogo Internacionala 17 ijunja - 8 ijulja 1924 g., Stenografičeskij oť̌et (Moscow, Leningrad, 1925), II (Priloženija), p. 237³

\footnotetext{
1 Fedor Raskol'nikov, born Fedor Il'in, attended the Fifth Congress as a member with voting rights of the $R C P(B)$ delegation under the name Raskol'nikov. He was also a member with a consultative vote of the delegation of the CP of China, under the pseudonym Petrov. Under the name Petrov he directed the Eastern department of the ECCI for several years. He was apparently elected as candidate of the ECCI to the Secretariat and the Orgbureau for the Eastern countries. See source, pp. 241-43; Leo Trotzky, Wer leitet heute die Kommunistische Internationale (Berlin, 1930), p. 30.

- Béla Kun, relieved of all party positions in the Hungarian CP from 1922 un til the first congress of the Hungarian CP held in Vienna on 18-25 August 1925, attended the Fifth Comintern Congress as a full delegate with voting rights of the $\mathrm{RCP}(\mathrm{B})$ delegation. He directed the Agitprop department of the ECCI from December 1923 on. In 1924 he was elected as candidate to the ECCI, personally. See source, p. 242; Kun Bélané, Kun Béla (Emlékezések) (Budapest, 1966); Protokoll Fünfter Kongress der Kommunistischen Internationale (Hamburg, n.d.), p. 1022.

s The German edition of the report omits Schüller, Hessen and Vujović as members, and Petrov as candidate. It mentions Sokolnikov as candidate. Filipović, Kaclerović, Marković, Maslow, Scoccimarro and Chen Tu-hsiu are listed under their pseudonyms: Bošković, Marinović, Simić, Robert, Marco and Tschin Du-liu. Protokoll Fünfter Kongress, pp. 1021-22. The English edition of the report does not give the names of Foster and Ruthenberg; it mentions only "United States: 2 comrades". Petrov is not named as candidate, but Sokolnikov is. Filipović, Kaclerović, Marković, Maslow and Scoccimarro are given under their pseudonyms. Fifth Congress of the Communist International, op. cit., pp. 277-78.
} 


\section{Table 24. The ICC elected at the Fifth Congress}

$\begin{array}{llll}\text { USSR } & \text { Kon; Sol'c, Aron A. } & & \\ \text { Brazil } & \text { Astrogildo (Pereira, } & \text { Germany } & \text { Koenig, Arthur } \\ & \text { Astrojildo) } & \text { Italy } & \text { Gennari } \\ \text { Britain } & \text { Murphy, John T. } & \text { Latvia } & \text { Stučka } \\ \text { Bulgaria } & \text { Kabakčiev, Christo } & \text { Lithuania } & \text { Angaretis } \\ \text { Czechosl. } & \text { Kreibich } & \text { Mexico } & \text { Stirner } \\ \text { Denmark } & \text { Lauersen (Larsen, Axel), } & \text { Poland } & \text { Próchniak } \\ & \text { for Scandinavia } & \text { Turkey } & \text { Shafik (Deymer, Shafik } \\ \text { Estonia } & \text { Pögelmann } & & \text { Hüsnü) } \\ \text { France } & \text { Cachin, Marcel } & \text { USA } & \text { Browder, Earl Russell }\end{array}$

Source: Pjatyj Vsemirnyj Kongress, II, p. 238

\section{Table 25. The Presidium of the ECCI elected at the 4th enlarged plenum} (12-13 July 1924)

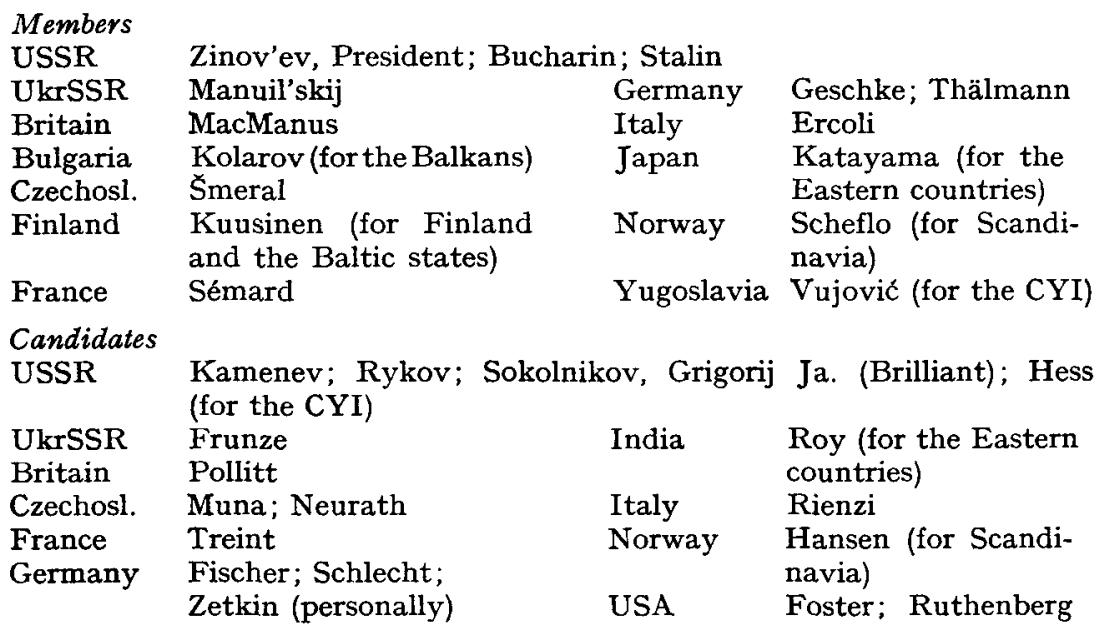

Source: 10 Let Kominterna, pp. $327-28^{1}$

Table 26. The Secretariat of the ECCI elected at the 4th enlarged plenum Members

$\begin{array}{lll}\text { USSR } & \text { Pjatnickij } & \text { Germany } \\ \text { Finland } & \text { Kuusinen } & \text { Switzerland Humbert-Droz (person- } \\ \text { France } & \text { Treint } & \text { ally?) }\end{array}$

1 Inprekorr, Vol. 4, p. 1107, lists Pollitt as a member of the Presidium, but fails to mention Foster and Ruthenberg as candidates. It 1 efers merely to "two American comrades". J. Degras, II, p. 573, says that the names of Roy and Hessen are omitted from the list published in 10 Let Kominterna. This is not correct. See source, p. 328.

2 Humbert-Droz represented the ECCI in the Latin countries of Europe from 1922 to 1924, and later became responsible for these countries and Latin America in the ECCI Secretariat in Moscow. He attended the Fifth Congress as a full delegate with voting rights of the Portuguese CP. $\mathrm{He}$ was probably elected personally to the Secretariat and the Orgbureau. See Pjatyj Vsemirnyj Kongress, II, p. 242. 
Candidates

Britain MacManus Germany Zetkin, for the IWS ${ }^{1}$

Czechosl. Neurath

Source: Inprekorr, Vol. 4, p. 1107 (14 July 1924)

\section{Table 27. The Orgbureau elected at the 4th enlarged plenum}

$\begin{array}{llll}\text { USSR } & \text { Pjatnickij; Petrov (for the Eastern countries?) } \\ \text { Austria } & \text { Schüller (for the CYI) } & \text { Italy } & \text { one representative } \\ \text { Britain } & \text { MacManus } & \text { Lithuania } & \text { Mickiewicz-Kapsukas } \\ \text { Czechosl. } & \text { one representative } & \text { Poland } & \text { Bogucki } \\ \text { Finland } & \text { Kuusinen } & \text { Switzerland Humbert-Droz (person- } \\ \text { France } & \text { Treint } & & \text { ally?) } \\ \text { Germany } & \text { Geschke } & \text { USA } & \text { Dunne } \\ \text { Hungary } & \text { Kun (personally) } & & \end{array}$

Source: ibid. Table 28. The Orgbureau elected at the 5th enlarged plenum (21 March-
6 April 1925)

USSR Pjatnickij; Petrov (for the Eastern countries?)

Austria Schüller (for the CYI) Lithuania Mickiewicz-Kapsukas

Britain MacManus

Finland Kuusinen

France Treint

Germany Geschke

Poland Bogucki

Hungary Kun (personally)

Switzerland Humbert-Droz (personally?)

Source: 10 Let Kominterna, p. 328

Table 29. The Presidium of the ECCI elected at the 6th enlarged plenum (17 February - 15 March 1926) $^{3}$

Members

USSR Zinov'ev, President; Bucharin; Stalin; Lominadze, Vissarion V., for the CYI; Lozovskij, for the RILU

\begin{tabular}{|c|c|c|c|}
\hline UkrSSR & $\begin{array}{l}\text { Manuil'skij } \\
\text { Ferguson. Aitke }\end{array}$ & Finland & $\begin{array}{l}\text { Kuusinen, for Finland } \\
\text { and the Baltic states }\end{array}$ \\
\hline 1 & Kolarov, for the & Fran & Sémard; Treint \\
\hline & Balkans & Germany & Remmele, Hermann; \\
\hline & $\begin{array}{l}\text { Su-Fan (Chen Ho-sian?) } \\
\text { Smeral }\end{array}$ & & $\begin{array}{l}\text { Thälmann; Zetkin (for } \\
\text { the IWS) }\end{array}$ \\
\hline
\end{tabular}

${ }^{1}$ Clara Zetkin was elected to the ECCI personally and as candidate to the Secretariat for the International Women's Secretariat (IWS). See source.

2 The 5th plenum does not appear to have published a list of members elected to the ECCI Presidium and Secretariat. J. Degras, II, p. 573, gives a list of the composition of the Secretariat consisting of Kuusinen, Pjatnickij, Treint, Katz, Humbert-Droz, Neurath and Kornblum. This composition is in accordance with the list of the Secretariat elected at the opening of the plenum for the duration of the plenum only. See, for instance, Protokoll der Erweiterten Exekutive der Kommunistischen Internationale, Moskau, 21. März - 6. April 1925 (Hamburg, 1925), pp. 1, 4. * On 17 March 1926 Bucharin, Thälmann and Sémard were elected as Vice-Presidents of the Comintern and the ECCI. See source. 


\begin{tabular}{|c|c|c|c|}
\hline India & $\begin{array}{l}\text { Roy, for the Eastern } \\
\text { countries }\end{array}$ & $\begin{array}{l}\text { Japan } \\
\text { USA }\end{array}$ & $\begin{array}{l}\text { Katayama } \\
\text { Ruthenberg }\end{array}$ \\
\hline Italy & Ercoli & & \\
\hline $\begin{array}{l}\text { Candidates } \\
\text { Bulgaria } \\
\text { Poland } \\
\text { USA }\end{array}$ & $\begin{array}{l}\text { Dimitrov, Georgi } \\
\text { Bogucki } \\
\text { Bedacht, Max }\end{array}$ & Yugoslavia & $\begin{array}{l}\text { Bošković, Boško (Fili- } \\
\text { pović, Filip); Vujović, } \\
\text { for the CYI }\end{array}$ \\
\hline
\end{tabular}

Source: Inprekorr, Vol. 6, p. 794 (9 April 1926)

Table 30. The Secretariat of the ECCI elected at the 6th enlarged plenum

\begin{tabular}{|c|c|c|c|}
\hline $\begin{array}{l}\text { Members } \\
\text { USSR }\end{array}$ & Kornblum, Isak R.; P & ij; Petrov (fo & r the Eastern countries?) \\
\hline Britain & Ferguson & India & Roy, for the Eastern \\
\hline Czechosl. & Smeral & & countries \\
\hline Finland & Kuusinen, for Finland & Italy & Ercoli \\
\hline & and the Baltic states & Switzerland & Humbert-Droz (person- \\
\hline France & Jacob, Henri & & ally?) \\
\hline Germany & Geschke & & \\
\hline Candidates & & & \\
\hline Bulgaria & Dimitrov, Georgi & USA & $\begin{array}{l}\text { Pepper, John (Pogány, } \\
\text { József) (personally?) }\end{array}$ \\
\hline
\end{tabular}

Source: ibid.

\section{Table 31. The Orgbureau elected at the 6th enlarged plenum}

\begin{tabular}{|c|c|c|c|}
\hline $\begin{array}{l}\text { Members } \\
\text { USSR }\end{array}$ & Piatnickii: Petroy (for & istern countr & \\
\hline UkrSSR & Fatricks, Fetror (10) & astern countr & res!) \\
\hline UkrSSR & Manuil'ska & Germany & Greschke \\
\hline Britain & Ferguson & India & Roy (for the Eastern \\
\hline Bulgaria & Dimitrov, Georgi & & countries) \\
\hline Czechosl. & Smeral & Italy & Ercoli \\
\hline Finland & $\begin{array}{l}\text { Kuusinen (for Finland } \\
\text { and the Baltic states) }\end{array}$ & Switzerland & $\begin{array}{l}\text { Humbert-Droz (person- } \\
\text { ally?) }\end{array}$ \\
\hline France & Treint & & \\
\hline
\end{tabular}

In addition, the heads of the ECCI departments and the representatives of the ECCI Co-operative department, the CYI and the IWS

\section{Candidates}

$\begin{array}{llll}\text { USSR } & \text { Kornblum } & \text { USA } & \text { Pepper (personally?) } \\ \text { France } & \text { Jacob } & & \end{array}$

Source: ibid.

1 Jozsef Pogany was a member of the Hungarian CP from 1919 until 1922, and from the summer of 1922 a member of the CPUSA under the assumed name of John Pepper. From 1925 on, be headed the Information department of the ECCI Secretariat in Moscow. He was probably elected as a candidate to the Secretariat and the Orgbureau for the ECCI apparatus personally. 
Table 32. The Presidium of the ECCI elected at the 7th enlarged plenum (22 November - 28 December 1926) ${ }^{1}$

\begin{tabular}{|c|c|c|c|}
\hline \multicolumn{4}{|l|}{ Members } \\
\hline USSR & \multicolumn{3}{|c|}{ Bucharin; Stalin; Lozovskij (for the RILU); Sackin (for the CYI) } \\
\hline UkrSSR & Manuil'skij & India & Roy (for the Eastern \\
\hline Britain & Gallacher; Murphy & & countries) \\
\hline \multirow[t]{2}{*}{ Bulgaria } & Kolarov (for the & Indonesia & Semaoen \\
\hline & Balkans) & Italy & Ercoli \\
\hline China & Tan-Pin (Tan Ping-shan) & Japan & Katayama \\
\hline Czechosl. & Haken, Josef; Smeral & Poland & Próchniak \\
\hline Finland & $\begin{array}{l}\text { Kuusinen (for Finland } \\
\text { and the Baltic states) }\end{array}$ & Sweden & $\begin{array}{l}\text { Sillen, Hugo (for } \\
\text { Scandinavia) }\end{array}$ \\
\hline $\begin{array}{l}\text { France } \\
\text { Germany }\end{array}$ & $\begin{array}{l}\text { Crémet, Jean; Sémard } \\
\text { Remmele; Thälmann; } \\
\text { Zetkin (for the IWS) }\end{array}$ & USA & $\begin{array}{l}\text { Duncan (Minor, } \\
\text { Robert); Ruthenberg }\end{array}$ \\
\hline \multicolumn{4}{|l|}{ Candidates } \\
\hline USSR & \multicolumn{3}{|c|}{ Molotov, Vjačeslav M. (Skrjabin); Pjatnickij } \\
\hline Argentina & Codovilla, Victorio (for & Hungary & Kun \\
\hline & America?) & Italy & Magg \\
\hline Aus & Schuiller (for the CYI) & Poland & Bogucki \\
\hline $\begin{array}{l}\text { France } \\
\text { Germany }\end{array}$ & $\begin{array}{l}\text { Treint } \\
\text { Geschke }\end{array}$ & Switzerland & $\begin{array}{l}\text { Humbert-Droz (person- } \\
\text { ally?) }\end{array}$ \\
\hline
\end{tabular}

Source: Inprekorr, Vol. 6, p. 2842 (23 December 1926)

\title{
Table 33. The Political Secretariat of the ECCI elected at the session of the Presidium of 20 December 1926
}

\author{
Members \\ USSR \\ UkrSSR \\ Bucharin; Pjatnickij \\ Manuil'skij \\ France Crémet \\ Czechosl. Smeral (personally?)2 \\ Germany Remmele \\ Finland Kuusinen (for Finland \\ India Roy (for the Eastern \\ and the Baltic states) \\ countries) \\ Italy Ercoli

\section{Candidates} \\ USSR \\ Molotov; Lozovskij \\ (for the RILU) \\ Britain Murphy \\ Switzerland Humbert-Droz (person- \\ ally?) \\ Source: ibid. ${ }^{3}$ \\ 1 This plenum relieved Zinov'ev from the Presidency of the Comintern and from his duties in \\ the ECCI. It proposed to abolish the post of President of the Comintern and the ECCI. The \\ Orgbureau and the Secretariat were abolished and merged in the Political Secretariat, created \\ at the close of the plenum. See Inprekorr, Vol. 6, p. 2522 (23 November 1926); Protokoll \\ Erweiterte Exekutive der Kommunistischen Internationale, Moskau, 22. November - 16. \\ Dezember 1926 (Hamburg, Berlin, 1927), pp. 842-44; Tätigkeitsbericht der Exekutive der \\ Kommunistischen Internationale, op. cit., p. 10. \\ - Bohumir Smeral, former leader of the Czechoslovak CP, was dispatched in 1926 for permanent \\ work in the Comintern apparatus in Moscow and gradually relieved of his party positions in the \\ Czechoslovak CP. In 1926-28 he headed the Balkan Secretariat of the ECCI in Moscow, and \\ was probably elected to the Political Secretariat for the ECCI apparatus personally. \\ - 10 Let Kominterna, p. 329, gives Bernard as a member of the Political Secretariat.
}


Table 34. The Presidium of the ECCI after the 8th plenum (18-30 May 1927) ${ }^{1}$

\begin{tabular}{|c|c|c|c|}
\hline Tembers & & & \\
\hline USSR & Bucharin; Stalin; Lozovskij & for the RIL & U; Sackin, for the CYI \\
\hline UkrSSR & Manuil'skij & India & Roy \\
\hline Britain & Gallacher; Murphy & Indonesia & Semaoen \\
\hline Bulgaria & Kolarov & Italy & Maggi \\
\hline China & Tan-Pin & Japan & Katayama \\
\hline Czechosl. & Haken; Smeral & Poland & Próchniak \\
\hline Finland & Kuusinen & Sweden & Sillen, for Scandinavia \\
\hline France & Bernard, Alfred; Sémard & USA & Duncan \\
\hline Grermany & $\begin{array}{l}\text { Remmele; Thälmann; } \\
\text { Zetkin, personally }\end{array}$ & & \\
\hline Candidates & & & \\
\hline USSR & Molotov; Pjatnickij & & \\
\hline Argentina & Codovilla, for South & Hungary & Kun \\
\hline & America? & Italy & Ercoli \\
\hline Austria & Schüller, for the CYI & Poland & Bogucki \\
\hline France & Treint & Switzerland & Humbert-Droz, person- \\
\hline Germany & Geschke & & ally? \\
\hline
\end{tabular}

Table 35. The Political Secretariat of the ECCI after the 8th plenum

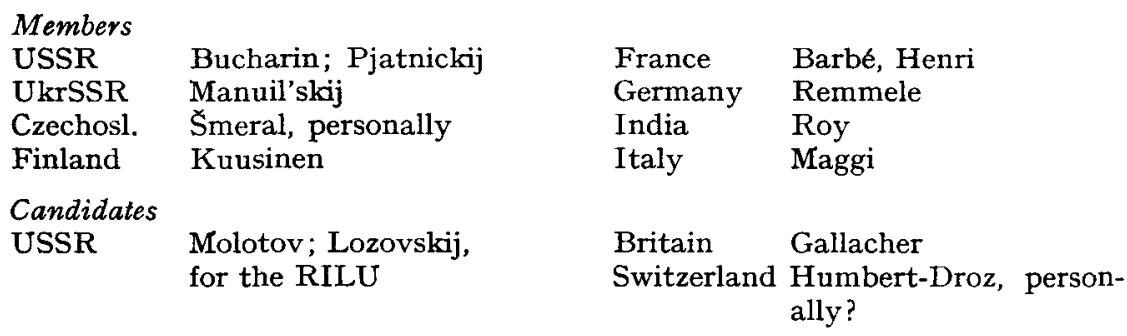

Table 36. The Presidium of the ECCI elected at the 9th plenum (9-25 February 1928)

\begin{tabular}{llll} 
Members & \multicolumn{3}{c}{} \\
USSR & Bucharin; Stalin; Lozovskij (for the RILU); Sackin (for the CYI) \\
UkrSSR & Manuil'skij & India & Roy \\
Britain & Gallacher; Murphy & Indonesia & Semaoen \\
Bulgaria & Kolarov & Italy & Ercoli; Maggi \\
China & Hsiang (Hsiang Chung- & Japan & Katayama \\
& fa) & Poland & Próchniak \\
Czechosl. & Jilek; Smeral & Sweden & Kilbom \\
Finland & Kuusinen & Switzerland Humbert-Droz (person- \\
France & Barbé; Sémard & & ally) \\
Germany & Remmele; Thälmann; & USA & Engdahl, J. Louis; \\
& Zetkin (personally) & & Foster
\end{tabular}

1 This plenum did not elect a Presidium and a Political Secretariat. For the attendant changes, see 10 Let Kominterna, pp. 328-29. 


\section{Candidates}

USSR Molotov; Pjatnickij

Austria Schüller (for the CYI)

Britain Arnot, Robin Page; Ben-

nett, A. J. (Lipec,

David) ${ }^{1}$

$\begin{array}{ll}\text { Germany } & \text { Geschke } \\ \text { Hungary } & \text { Kun } \\ \text { Italy } & \text { Vincenzi (pseud.) } \\ \text { Poland } & \text { Purman, Leon }\end{array}$

Source: 10 Let Kominterna, pp. $327-28^{2}$

\section{SIXTH CONGRESS (17 AUGUST - 1 SEPTEMBER 1928)}

\section{Table 37. The ECCI elected at the Sixth Congress}

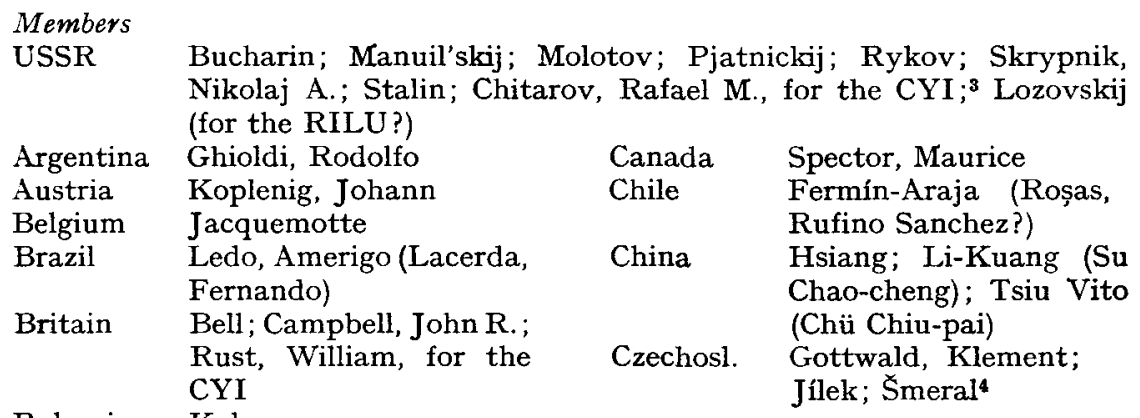

Bulgaria Kolarov

I A. J. Bennett was born in Berdičev in the Ukraine as David Lipec. He emigrated to the USA before World War I. There he used the name Dr Max Goldfarb and became a leading member of the Central Jewish Workers' Party, a member of the Bund, and a political writer on the Jewish Daily Forward. After the October Revolution, he returned to Russia and became a member of the RCP(B). During the Civil War, he served in the headquarters of the Red Army and joined the ECCI apparatus in Moscow under the name of D. Petrovskij. In the spring of 1924, under the name of A. J. Bennett, he was sent to Britain by the ECCI to act as its representative in the British CP. Later he did the same thing in the CP of France under the pseudonym Humbold. Bennett attended the Fifth and the Sixth Congresses of the Comintern as a full delegate with voting rights of the British CP. After the Sixth Congress he worked in the ECCI apparatus. At the beginning of the 1930's, he was accused of being a "Trotskyist" and expelled from the $\operatorname{RCP}(B)$. During Stalin's purges, he was arrested and disappeared without trace. See Pjatyj Vsemirnyj Kongress, II, p. 239; VI Kongress Kominterna, Stenografičeskij otčet (Moscow, Leningrad, 1929), V, p. 150; Melech Epstein, The Jew and Communism 1919-1941 (New York, 1959), p. 12; J. T. Murphy, New Horizons (London, 1941), pp. 251, 287-88; Jules HumbertDroz, Mémoires, De Lénine à Staline 1921-1931 (Neuchâtel, 1971), p. 277.

Degras, II, p. 574, gives Weinstein as candidate of the ECCI Presidium; she omits Vincenzi. 3afael Chitarov, of Armenian origin, born near Tiflis, Caucasus, worked in Germany in 1921-25 under the assumed name Rudolf. He served as secretary of the regional committee of the Communist Youth League of Germany in the Ruhr, and in 1923-25 as the organizing secretary of its CC (Central Committee) in Berlin. In May 1927 he was sent to China by the CYI to act as its representative in the Chinese Communist Youth Corps. He took part in removing Chen Tu-hsiu from his post as secretary-general of the Chinese CP. See G. A. Avetisjan, Raffi Chitarov. Očerki žizni i dejatel'nosti (Erevan, 1971).

- Smeral took part in the Sixth Congress only as a consultative delegate without voting rights of the Czechoslovak CP. Although he had been re-elected to the ECCI, its Presidium and Political Secretariat for that $C P$, he was forbidden to attend the fifth congress of the latter (February 1929). He was not re-elected to the $\mathrm{CC}$ of the Czechoslovak CP until its seventh congress in 1936. See source, V, p. 156. 


\begin{tabular}{|c|c|c|c|}
\hline Finland & $\begin{array}{l}\text { Manner; Kuusinen, } \\
\text { personally }\end{array}$ & Lithuania & $\begin{array}{l}\text { Mickiewicz-Kapsukas, } \\
\text { for the Baltic states }\end{array}$ \\
\hline \multirow[t]{2}{*}{ France } & Barbé; Sémard; Thorez, & Mexico & Carrillo, Rafael \\
\hline & Maurice & Norway & Furubotn, Peder \\
\hline \multirow[t]{2}{*}{ Germany } & $\begin{array}{l}\text { Dengel, Philipp; Pieck, } \\
\text { Wilhelm; Remmele; } \\
\text { Thälmann; Blenkle, }\end{array}$ & Poland & $\begin{array}{l}\text { Leński, Julian (Le- } \\
\text { szczyński, Julian); } \\
\text { Próchniak }\end{array}$ \\
\hline & $\begin{array}{l}\text { Konrad, for the CYI; } \\
\text { Zetkin, personally }\end{array}$ & Rumania & $\begin{array}{l}\text { Popescu (Pauker, } \\
\text { Marcel) }\end{array}$ \\
\hline Greece & Syphneios (pseud.) & Sweden & Kilbom; Samuelson \\
\hline Hungary & Kun & Switzerland & Wieser, Fritz; Humbert- \\
\hline India & Chatterji (pseud.?) & & Droz, personally ${ }^{1}$ \\
\hline Indonesia & Musso & Turkey & Ferdi, B. Husein \\
\hline \multirow{2}{*}{ Italy } & Ercoli; Serra (Tasca, & & (pseud.) \\
\hline & Angelo) & Uruguay & Gomez, Eugenio \\
\hline \multirow[t]{2}{*}{ Japan } & Kato (Sano, Manabu); & $\mathrm{USA}$ & Foster; Lovestone, Jay \\
\hline & Katayama, personally & Yugoslavia & Bošković \\
\hline
\end{tabular}

\section{Candidates USSR}

Australia
Britain
Bulgaria
China

Colombia Ecuador Cuba Czechosl.

Denmark France
Gusev, Sergej I. (Drabkin, Jakov) ; ${ }^{2}$ Hopner, Serafima I. ; Jaroslavskij, Emel'jan M. (Hubelmann); Mojrova, Varvara A.
Kavanagh, Jack
Horner, Arthur; Pollitt
Dimitrov, Georgi
Chang Piao (Chang
Kuo-tau); Chen Kwang
(Chou En-lai); Guan-li
(pseud.), for the CYI
Riasco-Giulio (pseud.?)
Germany Ewert, Arthur; Heckert;
Schneller, Ernst;
Ulbricht, Walter
Visser, Louis de
Varga, Jenö, personally
Naoradji (pseud.)

Holland
Hungary
India
Indonesia
Italy
Darsono
Garlandi (Grieco, Rug-
Lopez (pseud.?)
Japan
Norway
Asano (Watanabe,
(Palestine?) Sauki (pseud.), for
Masanosuke)
Egypt, Palestine and gero); Turini (pseud.)
Reiman, Pavel; Verčik; Zápotocký
Thögersen, Thöger
Doriot; Frachon,
Benoît; Monmousseau,
Gaston; Billoux,
François, for the CYI
Poland

\footnotetext{
1 Humbert-Droz, head of the Latin Secretariat of the ECCI in Moscow at the time of the Sixth Congress, attended the Congress as a representative without voting rights of the ECCI apparatus. See source, V, p. 158.

Sergej Gusev participated in the Sixth Congress and delivered a speech, using the pseudonym Travin. See source, IV, pp. 232-41.

3 Nikolaj Popov, of Russian origin, born in Kutaisi (Georgia), was a member of the RCP(B) from 1919, and the author of the Outline History of the RCP(B) published in 1926. As a party official, he served in the central apparatus of the $R C P(B)$ in Moscow and in the Ukraine. He attended the Sixth Congress as a full delegate with voting rights of the $R C P(B)$ of the Ukraine, but was elected as a candidate to the ECCI for the Polish CP. Popov attended the six th plenum of the CC of the Polish CP held in Moscow in June 1929 as the representative of the ECCI, and was entrusted with the dismissal of the Kostrzewa-Warski group and with making Leński secretary-general. The Soviet literature does not mention Popov's membership of the ECCI for the Polish CP. See Sovetskaja Istoričeskaja Enciklopedija, XI (1963), pp. 410-11; Ckraïnska Radjan'skaja Enciklopedija, XI (1963), p. 392 ; source, V, p. 156.
} 


$\begin{array}{llll}\text { Poland, } & \text { Sokolik (Knorin, } & \text { USA } & \text { Gitlow, Benjamin; } \\ \text { continued } & \text { Vil'gel'm G.) } & & \text { Huiswoud, Otto E } \\ \text { South Africa Maloka (Malaka, Tan?) } & \text { Yugoslavia } & \text { Bosnić (Djaković, } \\ \text { Spain } & \text { Pascal (pseud.) } & & \text { Djuro) } \\ \text { Sweden } & \text { Sillen } & & \end{array}$

Source: VI Kongress Kominterna, II, pp. 198-99

\title{
Table 38. The ICC elected at the Sixth Congress
}

$\begin{array}{llll}\text { USSR } & \text { Cchakaja; Kon; Sol'c } & \text { Germany } & \text { Eberlein; Flieg, Leo } \\ \text { Argentina } & \text { Codovilla } & \text { Italy } & \text { Maggi } \\ \text { Bulgaria } & \text { Iskrov, Petar } & \text { Latvia } & \text { Stučka (Chairman) } \\ \text { China } & \text { Cheng Chen (pseud.); } & \text { Lithuania } & \text { Angaretis } \\ & \text { Hsiu Yen(Hsiang Ying?) } & \text { Persia } & \text { Shargi (pseud.) } \\ \text { Czechosl. } & \text { Mondok, Ivan;' Weiss } & \text { Rumania } & \text { Stefanescu (pseud.?) } \\ \text { Estonia } & \text { Anvelt, Jan } & \text { USA } & \text { Weinstone, William W. } \\ \text { Finland } & \text { Sirola } & \text { Yugoslavia Gorkić, Milan (Čižinski, } \\ \text { France } & \text { Cachin } & & \text { Josip), for the CYI }\end{array}$

Source: ibid.

\section{Table 39. The Presidium of the ECCI elected at the plenary session after the Sixth Congress (5 September 1928)}

\author{
Members \\ USSR Bucharin; Manuil'skij; Molotov; Pjatnickij; Stalin; Chitarov (for \\ the CYI); Lozovskij (for the RILU?) \\ Britain Bell \\ Bulgaria Kolarov (for the Balkans) \\ China Tsiu-Vito \\ CzechosI. Jílek; Smeral \\ Finland Kuusinen (personally) \\ France Barbé; Sémard
Germany Remmele; Thälmann;
Zetkin (personally)
Hungary Kun
Indonesia Musso
Italy Ercoli; Serra
Japan Kato; Katayama (per- sonally)

\footnotetext{
1 Vil'gel'm Knorin, born Wilhelm Knorinš, of Latvian origin, was a member of the RCP(B) from 1917. For several years he headed the Information and later Agitprop departments in the central apparatus of the $\mathrm{RCP}(\mathrm{B})$ in Moscow. At the fifteenth congress of the $\mathrm{RCP}(\mathrm{B})$ in 1927 he was elected a member of the $C C$ of the $R C P(B)$ and became first secretary of the Belorussian CP. Knorin attended the Sixth Comintern Congress as the head of the Belorussian delegation, but was elected as a candidate to the ECCI for the Polish CP under the pseudonym of Sokolik and became de facto head of that party. He went to Berlin, where the Politbureau of the Polish $\mathrm{CC}$ resided. Moreover, Knorin directed the West European Bureau of the ECCI in Berlin under the pseudonyms of Sokolik and Tischler until April 1929. At the sixth plenum of the Polish CC he reported on the situation in the RCP(B) and was elected a member of the Politbureau of the Polish CC. He played an active role in removing the Kostrzewa-Warski group. Knorin headed the Central European Secretariat of the ECCI until 29 April 1934. Soviet literature does not mention Knorin's membership of the ECCI for the Polish CP or his activities in that CP. See Bol'šaja Sovetskaja Enciklopedija, XII (1973), p. 344.

2 Ivan Mondok, who emigrated to the Soviet Union in 1929, was excluded from the ICC at the 13 th ECCI plenum in December 1933. He was arrested by the State Security organs of the USSR and sentenced to ten years of hard labour, and died in prison in 1941. See the report of Popov in XIII Plenum IKKI, Stenografičeskij otčet (Moscow, 1934), pp. 111-16.
} 


\section{Poland Próchniak \\ S. America Rosso (pseud.) \\ Sweden Kilbom (for Scandi- navia) \\ Candidates

$\begin{array}{llll}\text { Britain } & \text { Pollitt; Rust (for the } & \text { Poland } & \text { Leński; Purman } \\ & \text { CYI) } & \text { USA } & \text { Foster } \\ \text { China } & \text { Chang Piao } & \text { Yugoslavia } & \text { Milkovic (Sakun, } \\ \text { Germany } & \text { Heckert } & & \text { V(iktor?)) }{ }^{2}\end{array}$ \\ Norway Hansen (for Scandinavia) \\ Source: Inprekorr, Vol. 8, p. 2115 (2 October 1928) \\ Table 40. The Political Secretariat of the ECCI elected at the session of the Presidium of 5 September 1928}

\author{
Members \\ USSR Bucharin; Molotov; Pjatnickij \\ Britain Bell France Barbé \\ China Tsiu Vito Germany Remmele \\ Czechosl. Smeral Italy Serra \\ Finland Kuusinen (personally) Switzerland Humbert-Droz (person- \\ ally) \\ Candidates \\ USSR Manuil'skij; Chitarov (for the CYI); Lozovskij (for the RILU?) \\ Source: Inprekorr, Vol. 8, p. $2117^{\mathrm{s}}$

\section{Table 41. The Presidium of the ECCI after the 10th plenum (3-9 July $1929)^{4}$}

\author{
Members \\ USSR
}

Gusev; Manuil'skij; Molotov; Pjatnickij; Stalin; Chitarov (for the CYI); Lozovskij (for the RILU??)

${ }^{1}$ Cf. 10 Let Kominterna, p. 341.

2 V. Sakun, of Georgian origin, born in the Caucasus, was a member of the RCP(B) and worked in the apparatus of the Balkan Secretariat of the ECCI in Moscow from 1926. Early in 1928 be was sent to investigate the situation in the Yugoslav CP. Under the pseudonym Milkovic, he took part in the eighth conference of the CPY, held in Zagreb at the end of February 1928 as the representative of the ECCI. After the conference he submitted a report to the Balkan Secretariat, which played an important role in the removal of the Yugoslav leadership headed by Sima Marković. A conference of the CPY, organized by the Balkan Secretariat and held in Moscow in April 1928, removed the old leadership. See Mane Trbojević, VIII Mjesna Konferencija Zagrebačke Organizacije KPJ (Grada) (Zagreb, 1970), p. 19.

10 Let Kominterna, p. 341, gives Ulbricht instead of Remmele as a member of the Political Secretariat; it mentions that Milkovic was elected as candidate to the Presidium for the Balkans and Heckert for the RILU. Chü Chiu-pai is added under the pseudonym Strachov.

- This plenum carried out supplementary elections to the Presidium. It excluded Jilek, Lovestone and Spector from the ECCI. For the attendant changes, see Protokoll 10. Plenum des Exekutivkomitees der Kommunistischen Internationale, Moskau, 3. Juli 1929 bis 19. Juli 1929 (Hamburg, Berlin, n.d.), pp. 878-80. The name Randolph is sometimes spelled Randolf. 


\begin{tabular}{|c|c|c|c|}
\hline Brazil & Ledo, for South America & Hungary & Kun \\
\hline Britain & Bell & Indonesia & Musso \\
\hline Bulgaria & Kolarov (for the & Italy & Ercoli; Garlandi \\
\hline & Balkans) & Japan & Kato; Katayama \\
\hline China & Tsiu Vito & & (personally) \\
\hline Czechosl. & $\begin{array}{l}\text { Gottwald; Smeral } \\
\text { (personally) }\end{array}$ & $\begin{array}{l}\text { Poland } \\
\text { S. America }\end{array}$ & $\begin{array}{l}\text { Leński; Próchniak } \\
\text { Rosso }\end{array}$ \\
\hline Finland & Kuusinen (personally) & Sweden & Kilbom (for \\
\hline France & Barbé; Sémard & & Scandinavia) \\
\hline Germany & $\begin{array}{l}\text { Remmele; Thälmann; } \\
\text { Zetkin (personally) }\end{array}$ & USA & $\begin{array}{l}\text { Randolph (Weinstone, } \\
\text { William W.) }\end{array}$ \\
\hline \multicolumn{4}{|l|}{ Candidates } \\
\hline Britain & $\begin{array}{l}\text { Pollitt; Rust (for the } \\
\text { CYI) }\end{array}$ & Norway & $\begin{array}{l}\text { Hansen (for } \\
\text { Scandinavia) }\end{array}$ \\
\hline China & Chang Piao & Poland & Purman \\
\hline Czechosl. & Reiman & USA & Foster \\
\hline Germany & Heckert & Yugoslavia & Milković \\
\hline
\end{tabular}

Table 42. The Political Secretariat of the ECCI after the 10th plenum

Members

USSR Molotov; Pjatnickij

Britain Bell Finland Kuusinen (personally)

China Tsiu Vito France Barbé

Czechosl. Smeral (personally) Germany Remmele

Candidates

USSR Manuil'skij; Chitarov (for the CYI); Lozovskij (for the RILU?)

Table 43. The Presidium of the ECCI elected at the 11th plenum (25 March - 13 April 1931)

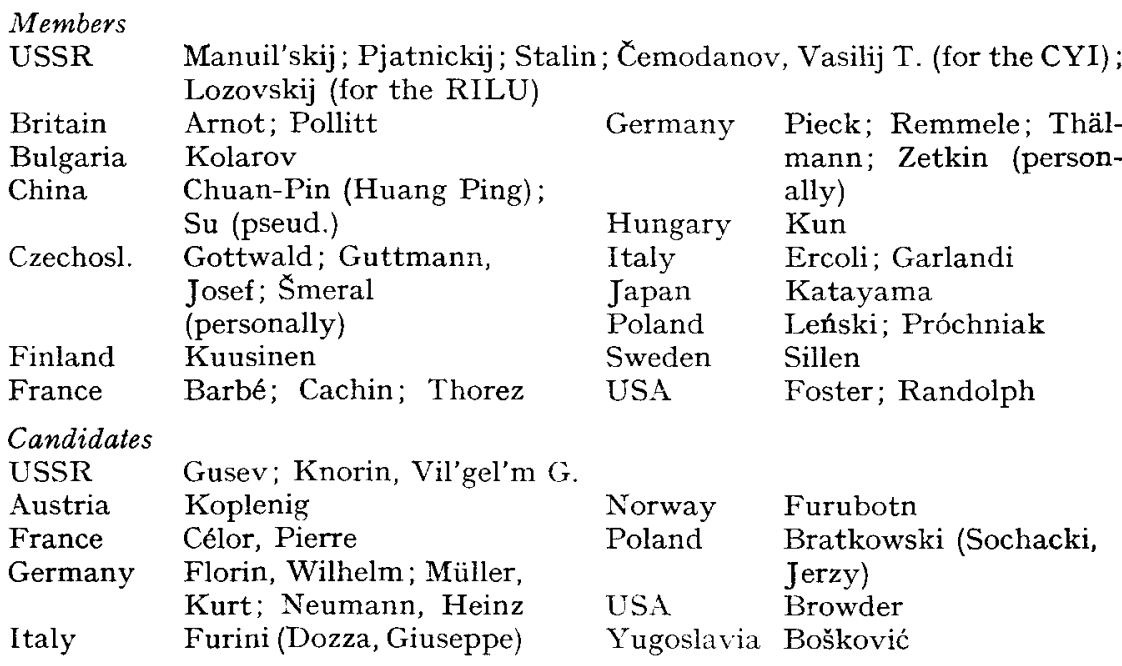

Source: XI Plenum IKKI, Stenografičeskij otčet (Moscow, Leningrad, 1931), II, p. 246 
Table 44. The Political Secretariat of the ECCI elected at the session of the Presidium of 15 April 1931

$\begin{array}{llll}\begin{array}{l}\text { Members } \\ \text { USSR }\end{array} & \text { Knorin; Manuil'skij; Pjatnickij } & \\ \text { Britain } & \text { Pollitt } & \text { Germany } & \text { Pieck; Thälmann } \\ \text { China } & \text { Chuan-Pin } & \text { Italy } & \text { Ercoli } \\ \text { Czechosl. } & \text { Guttmann } & \text { Poland } & \text { Leński } \\ \text { Finland } & \text { Kuusinen (personally) } & \text { USA } & \text { Randolph } \\ \text { France } & \text { Thorez } & & \\ \text { Candidates } & & & \\ \text { USSR } & \text { Cemodanov (for the CYI) } & \text { Lozovskij (for the RILU) } \\ \text { Britain } & \text { Arnot } & \text { Italy } & \text { Furini } \\ \text { France } & \text { Célor } & \text { Poland } & \text { Bratkowski } \\ \text { Source: ibid. } & & & \end{array}$

Table 45. The Presidium of the ECCI after the 12th plenum (27 August15 September 1932) ${ }^{1}$

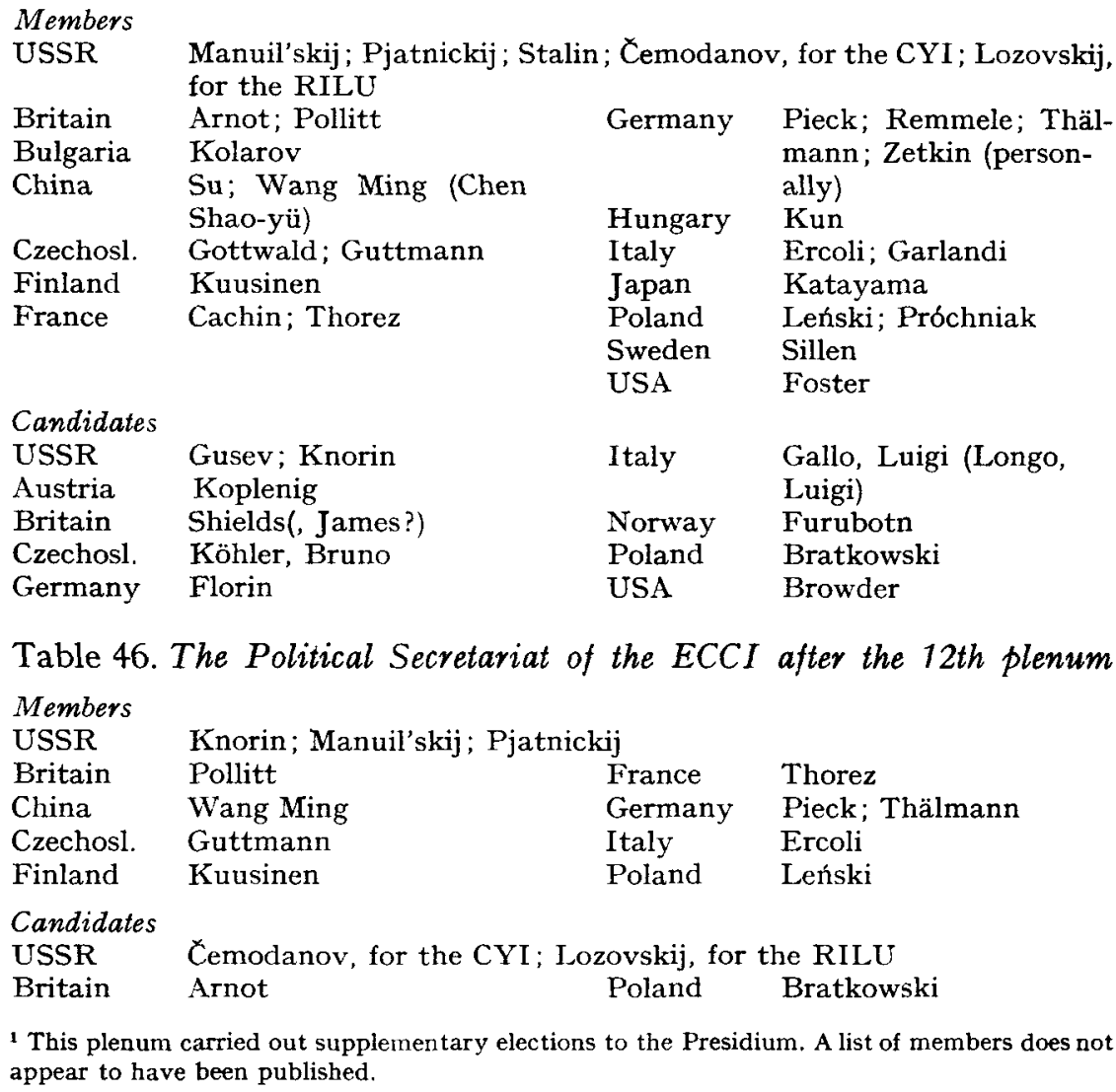


Table 47. The Presidium of the ECCI after the 13th plenum (28 November - 12 December 1933) ${ }^{1}$

\begin{tabular}{|c|c|c|c|}
\hline \multicolumn{4}{|l|}{ Members } \\
\hline USSR & \multicolumn{3}{|c|}{$\begin{array}{l}\text { Manuil'skij; Pjatnickij; Stalin; Cemodanov, for the CYI; Lozovski } \\
\text { for the RILU }\end{array}$} \\
\hline Britain & Gallacher; Pollitt & Hungary & Kun \\
\hline Bulgaria & Kolarov & Italy & Ercoli; Garlandi \\
\hline China & $\begin{array}{l}\text { Kang Sin (Kang Sheng); } \\
\text { Wang Ming }\end{array}$ & Japan & $\begin{array}{l}\text { Okano, Susumu } \\
\text { (Nosako, Sanzo) }\end{array}$ \\
\hline Czechosl. & Gottwald; Köhler & Poland & Leński; Próchniak \\
\hline Finland & Kuusinen & Sweden & Sillen \\
\hline France & Cachin; Thorez & USA & Foster \\
\hline Germany & Florin; Pieck; Thälmann & & \\
\hline \multirow{7}{*}{$\begin{array}{l}\text { Candidates } \\
\text { USSR } \\
\text { Austria } \\
\text { Britain } \\
\text { Czechosl. } \\
\text { Germany }\end{array}$} & & \multirow{3}{*}{ Italy } & \\
\hline & Knorin & & Roncoli (Montagnana, \\
\hline & Koplenig & & Mario) \\
\hline & MacIlhon (pseud.?) & Norway & Furubotn \\
\hline & Haken & Poland & Bronkowski (Bort- \\
\hline & Heckert & & nowski, Bronislaw) \\
\hline & & USA & Browder \\
\hline
\end{tabular}

Table 48. The Political Secretariat of the ECCI after the 13th plenum

Members

USSR Knorin; Manuil'skij; Pjatnickij

$\begin{array}{llll}\text { Britain } & \text { Pollitt } & \text { Germany } & \text { Pieck; Thälmann } \\ \text { China } & \text { Wang Ming } & \text { Italy } & \text { Ercoli }\end{array}$

Finland Kuusinen Poland Leński

France Thorez

Candidates

USSR Cemodanov, for the CYI; Lozovskij, for the RILU

Poland Bronkowski

\section{SEVENTH CONGRESS (25 JULY - 20 AUGUST 1935)}

\section{Table 49. The ECCI elected at the Seventh Congress}

Members

USSR

Austria

Brazil
Ežov, Nikolaj I.; Manuil'skij; Moskvin, Michail A. (Trilisser, Mejer A.); Stalin; Ždanov, Andrej A.
Koplenig

Prestes, Luis Carlos

\footnotetext{
1 For the changes brought about by the supplementary elections of this plenum, see XIII Plenum IKKI, pp. 569-70. This report omits the name of Bronkowski, who replaced Bratkowski as candidate to the Presidium and the Political Secretariat. The latter was arrested by the State Security organs of the USSR in August 1933, and committed suicide on September 4 in a Moscow prison cell. See "Autobiografia Bronisłava Bortnowskiego-Bronkowskiego", in: Z Pola Walki, VII (1964), No 4, pp. 195-200; "Jerzy Czeszejko-Sochacki", ibid., III (1960), No 4, pp. 128-47.
} 


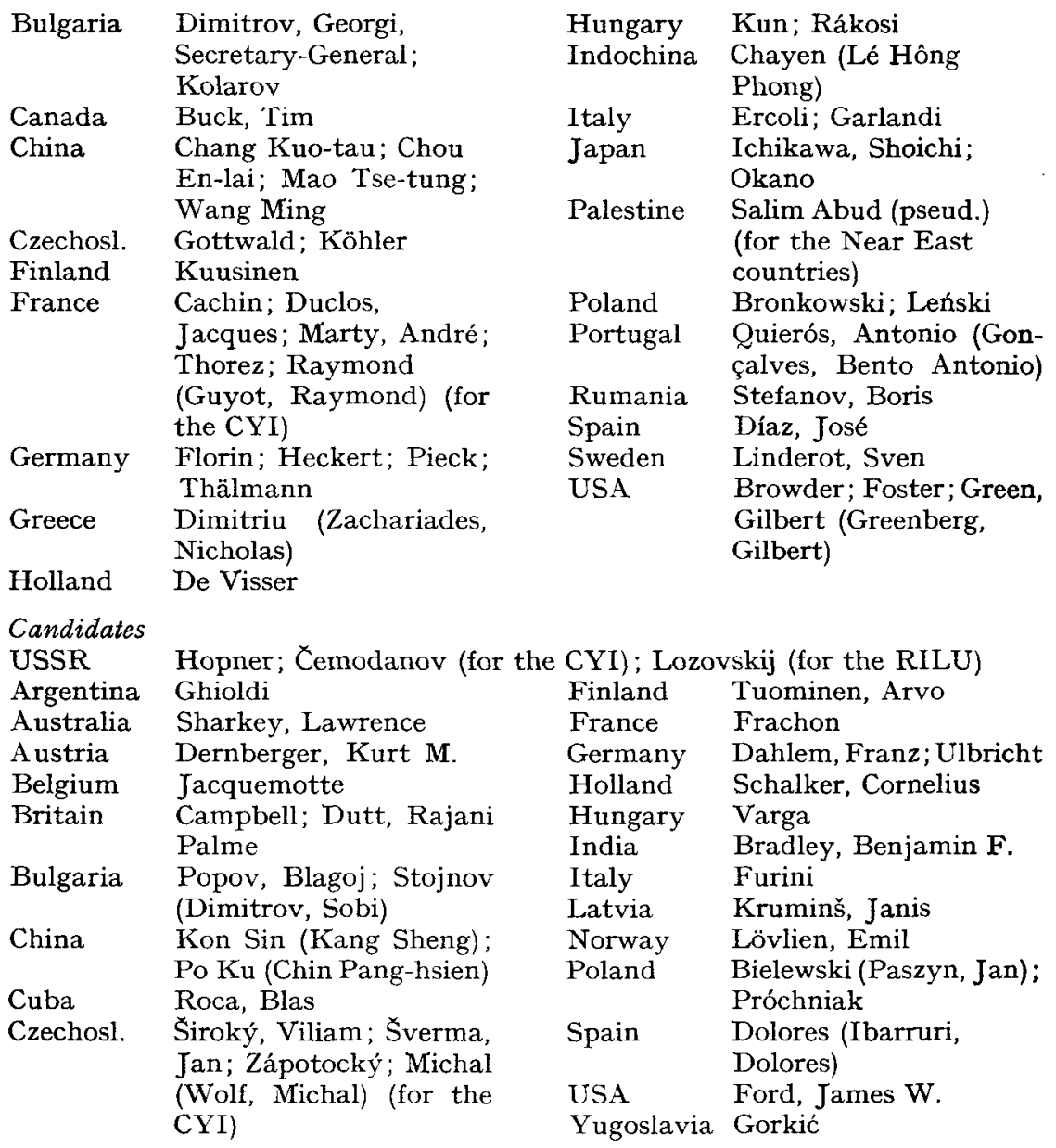

Source: Pravda, 21 August 1935

\section{Table 50. The ICC elected at the Seventh Congress}

$\begin{array}{llll}\text { USSR } & \text { Cchakaja; Skirjatov, Matvej F.; Stasova, Elena D. } \\ \text { Britain } & \text { Kerrigan, Peter } & \text { Italy } & \text { Maggi } \\ \text { Bulgaria } & \text { Iskrov } & \text { Lithuania } & \text { Angaretis } \\ \text { China } & \text { Tu Ho Sin (No Kao Tsi- } & \text { Poland } & \text { Grzegorzewski; Krajew- } \\ & \text { li) } & & \begin{array}{l}\text { ski, Antoni (Stein, Wła- } \\ \text { dysław); Walecki }\end{array} \\ \text { Czechosl. } & \text { Śmeral } & \text { Sweden } & \text { Senander, Knut } \\ \text { Estonia } & \text { Anvelt (Chairman) } & \text { Turkey } & \text { Ferdi } \\ \text { Finland } & \text { Sirola } & \text { US.1 } & \text { Minor, Robert } \\ \text { France } & \text { Monmousseau } & & \\ \text { Germany } & \text { Dengel; Eberlein } & & \end{array}$

Source: ibid. 
Table 51. The Presidium of the ECCI elected at the plenary session after the Seventh Congress (21 August 1935)

\begin{tabular}{|c|c|c|c|}
\hline \multicolumn{4}{|l|}{ Members } \\
\hline USSR & \multicolumn{3}{|l|}{ Manuil'skij; Moskvin; Stalin } \\
\hline Austria & Koplenig & France & Cachin; \\
\hline Britain & Pollitt & Germany & Florin; \\
\hline Bulgaria & $\begin{array}{l}\text { Dimitrov, Georgi, Secre- } \\
\text { tary-General; Kolarov }\end{array}$ & $\begin{array}{l}\text { Italy } \\
\text { Japan }\end{array}$ & $\begin{array}{l}\text { Ercoli } \\
\text { Okano }\end{array}$ \\
\hline China & Wang Ming & Poland & Leński \\
\hline Czechosl. & Gottwald & USA & Foster \\
\hline Finland & Kuusinen & & \\
\hline \multicolumn{4}{|l|}{ Candidates } \\
\hline USSR & Lozovskij (for the RILU) & & \\
\hline Britain & Gallacher & Germany & Heckert \\
\hline China & Kon Sin & Italy & Garlandi \\
\hline Czechosl. & Köhler; Michal (for the & Poland & Bronkov \\
\hline & CYI) & Sweden & Linderot \\
\hline Finland & Tuominen & USA & Browder \\
\hline France & Raymond (for the CYI) & & \\
\hline \multicolumn{4}{|c|}{ Source: Pravda, 22 August 1935} \\
\hline \multicolumn{4}{|c|}{$\begin{array}{c}\text { Table 52. The Secretariat of the ECCI elected at the session of } \\
\text { of } 21 \text { August } 1935\end{array}$} \\
\hline \multicolumn{4}{|l|}{ Members } \\
\hline USSR & Manuil'skij & Finland & Kuusinen \\
\hline Bulgaria & $\begin{array}{l}\text { Dimitrov, Georgi, Secre- } \\
\text { tary-General }\end{array}$ & $\begin{array}{l}\text { France } \\
\text { Germany }\end{array}$ & $\begin{array}{l}\text { Marty } \\
\text { Pieck }\end{array}$ \\
\hline Czechosl. & Gottwald & Italy & Ercoli \\
\hline \multicolumn{4}{|l|}{ Candidates } \\
\hline USSR & Moskvin & Germany & Florin \\
\hline China & Wang Ming & & \\
\hline
\end{tabular}

Source: ibid.

\section{Table 53. The ECCI at the beginning of World War II}

$\begin{array}{llll}\begin{array}{l}\text { Members } \\ \text { USSR }\end{array} & \text { Manuil'skij; Stalin; Ždanov } & & \\ \text { Austria } & \text { Koplenig } & \text { Germany } & \text { Florin; Pieck; Thälmann } \\ \text { Brazil } & \text { Prestes } & \text { Greece } & \text { Dimitriu } \\ \text { Britain } & \text { Gallacher; Pollitt } & \text { Holland } & \text { De Visser } \\ \text { Bulgaria } & \text { Dimitrov, Georgi, Secre- } & \text { Hungary } & \text { Rákosi } \\ & \text { tary-General; Kolarov } & \text { Indochina } & \text { Chayen } \\ \text { Canada } & \text { Buck } & \text { Italy } & \text { Ercoli; Garlandi } \\ \text { China } & \text { Chou En-lai; Mao Tse- } & \text { Japan } & \text { Ichikawa; Okano } \\ & \text { tung; Wang Ming } & \text { Palestine } & \text { Salim Abud (for the } \\ \text { Czechosl. } & \text { Gottwald; Köhler } & & \text { Near East countries) } \\ \text { Finland } & \text { Kuusinen } & \text { Portugal } & \text { Quierós } \\ \text { France } & \text { Cachin; Duclos; Marty; } & \text { Rumania } & \text { Stefanov } \\ & \text { Thorez; Raymond, for } & \text { Spain } & \text { Díaz } \\ & \text { the CYI } & & \end{array}$




$\begin{array}{llll}\text { Sweden } & \text { Linderot } & \text { USA } & \text { Browder; Foster; } \\ \begin{array}{l}\text { Candidates } \\ \text { USSR }\end{array} & \text { Hopner; Lozovskij } & \text { Finland } & \text { Tuominen } \\ \text { Argentina } & \text { Ghioldi } & \text { France } & \text { Frachon } \\ \text { Australia } & \text { Sharkey } & \text { Germany } & \text { Dahlem; Ulbricht } \\ \text { Britain } & \text { Campbell; Dutt } & \text { Holland } & \text { Schalker } \\ \text { Bulgaria } & \text { Stojnov } & \text { Hungary } & \text { Varga } \\ \text { China } & \text { Kon Sin; Po Ku } & \text { India } & \text { Bradley } \\ \text { Cuba } & \text { Roca } & \text { Italy } & \text { Furini } \\ \text { Czechosl. } & \text { Siroký; Sverma; Zápo- } & \text { Norway } & \text { Lövlien } \\ & \text { tocký; Michal, for the } & \text { Spain } & \text { Dolores } \\ & \text { CYI } & \text { USA } & \text { Ford }\end{array}$

\section{Table 54. The ICC at the beginning of World War II}

$\begin{array}{llll}\text { USSR } & \text { Cchakaja; Skirjatov; Stasova } & \\ \text { Britain } & \text { Kerrigan } & \text { Germany } & \text { Dengel; Florin } \\ \text { China } & \text { Tu Ho-sin } & & \text { (Chairman) }^{1} \\ \text { Czechosl. } & \text { Smeral } & \text { Italy } & \text { Maggi } \\ \text { France } & \text { Monmousseau } & \text { Sweden } & \text { Senander } \\ & & \text { USA } & \text { Minor }\end{array}$

Table 55. The Presidium of the ECCI at the beginning of World War II

\begin{tabular}{|c|c|c|c|}
\hline \multicolumn{4}{|l|}{ Members } \\
\hline USSR & Manuil'skij; Stalin & & \\
\hline Austria & Koplenig & Finland & Kuusinen \\
\hline Britain & Pollitt & France & Cachin; Marty; Thorez \\
\hline Bulgaria & $\begin{array}{l}\text { Dimitrov, Georgi, Secre- } \\
\text { tary-General; Kolarov }\end{array}$ & $\begin{array}{l}\text { Germany } \\
\text { Italy }\end{array}$ & $\begin{array}{l}\text { Florin; Pieck } \\
\text { Ercoli }\end{array}$ \\
\hline China & Wang Ming & Japan & Okano \\
\hline Czechosl. & Gottwald & USA & Foster \\
\hline \multicolumn{4}{|l|}{ Candidates } \\
\hline USSR & Lozovskij & Finland & Tuominen ${ }^{3}$ \\
\hline Britain & Gallacher & France & Raymond, for the CYI \\
\hline China & Kon $\mathrm{Sin}$ & Italy & Garlandi \\
\hline Czechosl. & Köhler; Michal, for the & Sweden & Linderot \\
\hline & $\mathrm{CYI}^{2}$ & USA & Browder \\
\hline
\end{tabular}

1 Florin replaced Anvelt as member and chairman of the ICC in 1937. Anvelt was arrested in Moscow and shot.

2 Michal Wolf attended the 13th ECCI plenum as the representative of the Czechoslovak Communist Youth League under the pseudonym Michal in December 1933, and at the sixth congress of the CYI in October 1935 he was elected secretary. He was transferred from the Czechoslovak CP to the Hungarian CP in Moscow in 1940. During World War II he was employed at Radio Kossuth in Moscow and entrusted with political work among prisoners of war in the USSR. Assuming the name of Mihaly Farkas, he emigrated to Hungary at the end of 1944 and became a member of the Hungarian CP leadership. From 1948 to 1953 Farkas was a member of the Politbureau, deputy secretary-general of the Hungarian CP and Minister of National Defense. He was expelled from that party and arrested in 1956, sentenced in Budapest in 1957, but later released from prison. He died in 1965. See XIII Plenum IKKI, pp. 376-80; Munkásmozgalom történeti Lexikon (Budapest, 1972), p. 146.

s Tuominen was expelled from the ECCI and the Finnish CP at the end of 1939. 
Table 56. The Secretariat of the ECCI at the beginning of World War II 1

\begin{tabular}{|c|c|c|c|}
\hline $\begin{array}{l}\text { Members } \\
\text { USSR }\end{array}$ & Manuil'skij & & \\
\hline Bulgaria & $\begin{array}{l}\text { Dimitrov, Georgi, Secre- } \\
\text { tary-General }\end{array}$ & $\begin{array}{l}\text { France } \\
\text { Germany }\end{array}$ & $\begin{array}{l}\text { Marty } \\
\text { Pieck }\end{array}$ \\
\hline $\begin{array}{l}\text { Czechosl. } \\
\text { Finland }\end{array}$ & Gottwald & Italy & Ercoli \\
\hline Finland & Kuusinen & Spain & Díaz; Dolores \\
\hline $\begin{array}{l}\text { Candidates } \\
\text { China }\end{array}$ & Wang Ming & Germany & Florin \\
\hline
\end{tabular}

The resolution of the ECCI Presidium recommending the dissolution was signed by the following members: ${ }^{2}$

$\begin{array}{llll}\text { USSR } & \text { Manuil'skij; Ždanov } & & \\ \text { Austria } & \text { Koplenig } & \text { Finland } & \text { Kuusinen } \\ \text { Bulgaria } & \text { Dimitrov, Georgi; } & \text { France } & \text { Marty; Thorez } \\ & \text { Kolarov } & \text { Germany } & \text { Florin; Pieck } \\ \text { Czechosl. } & \text { Gottwald } & \text { Italy } & \text { Ercoli }\end{array}$

The following representatives of the Communist parties appended their signature to the resolution:

$\begin{array}{llll}\text { Finland } & \text { Lehtinen, Inkeri } & \text { Rumania } & \text { Pauker, Ana } \\ \text { Hungary } & \text { Rákosi } & \text { Spain } & \text { Ibarruri, Dolores } \\ \text { Italy } & \text { Bianco, Vincenzo } & & \end{array}$

Source: "Postanovlenie Prezidiuma Ispolnitel'nogo Komiteta Kommunističeskogo Internacionala", in: Kommunističeskij Internacional, 1943, No 5-6, pp. 8-10

\section{INDEX OF NAMES}

The numbers refer to the tables.

Ambrogi, E., 13, 14

Andrews, W., 16

Angaretis, Z. A., 5, 13, 24, 38, 50

Anvelt, J., 38, 50, $54 \mathrm{n}$.

Arnold, E., 5

Arnot, R. P., 36, 43, 44, 45, 46

Asano (Watanabe, M.), 37

Astrogildo (Pereira, A.), 24
Badulescu (Moscovici, G.), 5, Bennett, A. J. (Lipec, D.), 36, 13

\section{Balabanova, A., 1} $36 \mathrm{n}$.

Baldwin (Tywerousky, O.), 5 Berzin, J. A., 1, 1 n., 2

Barbé, H., 35, 36, 37, 39, 40, Bianco, V., 57 $41,42,43$

Bedacht, M., 29

Bielewski (Paszyn, J.), 49

5, 13, 37, 39, 40, Blenkle, K., 37

41, 42 Böttcher, P., 16

1 When Hitler attacked the USSR on 22 June 1941, an enlarged session of the ECCI Secretariat appointed a triumvirate consisting of Dimitrov, Manuil'skij and Ercoli. This was entrusted with the day-to-day management of the ECCI during World War II. See Meždunarodnoe Kommunističeskoe raboðee i nacional'noosvoboditel'noe dviženie, II (1939-1973 gg.) (Moscow, 1974), p. 21.

The resolution was signed only by those members of the ECCI Presidium living in the Soviet Union during World War II. Stalin, who was a member of the Presidium, was not among those who signed. It is not known how Z̆danov came to sign this resolution as a member of the Presidium. Officially he was elected only as an ECCI member at the Seventh Congress. 
Bogucki, W., 23, 27, 28, 29, 32, Chü Chiu-pai, see Strachov 34

Bordiga, A., 16, 20 n., 23

Bortnowski, B., see Bronkowski

Bošković, B. (Filipović, F see also sub voce), 23 n., 29, 37,43

Bosnić (Djaković, Dj.), 37

Bradley, B. F., 49, 53

Brand, E. (Lauer, H.), 21

Brandler, H., 9, 14

Bratkowski, J. (Sochacki, J.), $43,44,45,46,47 \mathrm{n}$.

Bronkowski (Bortnowski, B.), 47, 47 n., 48, 49, 51

Browder, E. R., 24, 43, 45, 47, $49,51,53,55$

Bucharin, N. I., 1, 1 n., 2, 3, 4, $5,6,9,12,13,14,16,17,20$, $23,25,29,29$ n., 32, 33, 34, $35,36,37,39,40$

Buck, T., 49, 53

Bunting, S. P., 13

Burian, E., 5

Cachin, M., 24, 38, 43, 45, 47, $49,51,53,55$

Calderio, F., see Roca, B.

Campbell, J. R., 37, 49, 53

Cannon, J. P., see Cook, J.

Carlo (Ljubarskij, N. M.), 1 n

Carr, J. (Katterfeld, L.), 9, 13, 14,16

Carrillo, R., 37

Cchakaja, M., 2, 5, 13, 38, 50, 54

Célor, P., 43, 44

Cemodanov, V. T., 43, 44, 45, $46,47,48,49$

Cesare (Sessa, C.?), 2, $2 \mathrm{n}$.

Chan-Kai, 5, 13

Chang Kuo-tau, 49

Chang Piao (Chang Kuo-tau, see also sub voce), $37,39,41$

Chatterji, 37

Chayen (Lé Hông Phong), 49, 53

Chen Kwang (Chou En-lai, see also sub voce), 37

Chen Shao-yü, see Wang Ming Ferdi, B. H., 37, 50

Chen Tu-hsiu, 23

Cheng Chen, 38

Chin Pang-hsien, see Po Ku

Chitarov, R. M., 37, 37 n., 39, $40,41,42$

Chou En-lai, 49, 53

Chuan-Pin (Huang Ping), 43, 44

Dunne, W. F., 23, 27, 28

\section{and Tsiu Vito}

Cičerin, G. V., 2 n.

Ciperovič, G. V., 2, 2 n.

Cižinski, J., see Gorkić, M.

Codovilla, V., 32, 34, 38

Cook, J. (Cannon, J. P.), 12, 13

Crémet, J., 32, 33

Cristescu, G., 23

Dahlem, F., 49, 53

Damon, D. (Ruthenberg, Ch. E., see also sub voce), 16

Darsono, 37

Dengel, Ph., 37, 50, 54

Dernberger, K. M., 49

Deymer, Sh. H., see Shafik

Díaz, J., 49, 53, 56

Dimitratos, P., 5, 13

Dimitriu (Zachariades, N.), 49 , 53

Dimitrov, G., 23, 29, 30, 31, 37, $49,51,52,53,55,56,56 \mathrm{n}$., 57

Dimitrov, S., see Stojnov

Djaković, Dj., see Bosnić

Dobrovolný, F., 23

Dolores (Ibarruri, D., see also sub voce) , 49, 53, 56

Doriot, J., 23, 37

Dozza, G., see Furini

Duclos, J., 49, 53

Duncan (Minor, R., see also sub voce), 32, 34

Duret, J. (Koral, F.), 16

Dutt, R. P., 49, 53

Earsman, W. P., 13

Eberlein, H., 10, 11, 13, 15, 38, 50

Engdahl, J. L., 36

Ercoli (Togliatti, P.), 23, 25 , $29,30,31,32,33,34,36,37$, $39,41,43,44,45,46,47,48$, $49,51,52,53,55,56,56 \mathrm{n}$. 57

Ewert, A., 37

Ferdi, B. H., 37, 50
Ferguson, A., 29, 30, 31

Fermin-Araja (Roşas, R. S.?), 37

Fiala, G., 23

Filipović, F., 23

Fischer, R. (Eisler, E.), 23, 25 Höglund, K. Z., 16, 23

Flieg, L., 38

Florin, W., 43, 45, 47, 49, 51, Hopner, S. 1., 37, 49, 53
$52,53,54,54$ n., $55,56,57$

Ford, J. W., 49, 53

Foster, W. Z., 23, 23 n., 25, 25 n., $37,39,41,43,45,47$, $49,51,53,55$

Frachon, B., 37, 49, 53

Freeman, P., 5

Friis, J., 2

Frölich, P., 5

Frossard, L.-O., 16

Frunze, M. V., 23, 25

Furini (Dozza, G.), 43, 44, 49, 53

Furubotn, P., 37, 43, 45, 47

Gallacher, W., 23, 32, 34, 35, $36,47,49,51,53,55$

Gallo, L. (Longo, L.), 45

Garden, J. S., 16

Garlandi (Grieco, R.), 37, 41, $43,45,47,49,51,53,55$

Gennari, E., 6, 16, 17, 24

Geschke, O., 23, 25, 26, 27, 28, $30,31,32,34,36$

Ghioldi, R., 37, 49, 53

Girault, S. (Depollier, S.), 23

Gitlow, B., 37, 39

Gliňski, P. (Królikowski, S.), 5

Gomez, E., 37

Gonçalves, B. A., see Quierós, A.

Gorkic, M. (Čižinski, J.), 38, 49

Gottwald, K., 37, 41, 43, 45, $47,49,51,52,53,55,56,57$

Gramsci, A., 12, 16, 17 n.

Green, G. (Greenberg, G.), 49, 53

Grieco, R., see Garlandi

Grzegorzewski (Grzelszczak, F.), 23, 50

Guan-Li, 37

Gusev, S. I. (Drabkin, Ja. D.), 37, 37 n., 41, 43, 45

Guttmann, J., 43, 44, 45, 46

Guyot, R., see Raymond

Haken, J., 32, 34, 47

Ham Man-chen, 5, 13

Hansen, A. G., 23, 25, 37, 39, 41

Heckert, F., 5, 6, 37, 39, 41, 47, 49,51

Henriet, P. A., 13

Hessen, S. M., 23, 23 n., 25, $25 \mathrm{n}$.

Hoernle, E., 16, 17, 19 
Horner, A., 37

Hsiang (Hsiang Chung-fa), 36, 37

Hsiang Chung-fa, see Hsiang

Hsiu Yen (Hsiang Ying?), 38

Huiswoud, O. E., 37

Hủla, B, 2, 2 n.

Humbert-Droz, J., 7, 13, 26, 26 n., 27, 28, 28 n., 30, 31, $32,33,35,36,37,37$ n., 39, 40

Hurvič, N., 2, 2 n.

Ibarruri, D., 57

Ichikawa, Sh., 49, 53

Iskrov, P., 38, 50

Jacob, H., 30, 31

Jacquemotte, J., 23, 37, 49

Jansen, J. (Proost, J.), 2, 2 n., 13

Jaroslavskij, E. M. (Hubelmann, M. I.), 37

Jerram, G., 23

Jílek, B., 12, 12 n., 36, 37, 39, $41 \mathrm{n}$.

Jörgensen, A., 5, 13

Jones, D. Y., 5

Jordanov, J., 12, 13, 14

Kabakčiev, Ch., 24

Kaclerović, T., 23

Kamenev, L. B. (Rosenfeld, L. B.), 5, 23, 25

Kang Sheng, see Kang Sin and Kon Sin

Kang Sin (Kang Sheng), 47

Karachan, L. M., 1

Kasjan, S. (Ter-Kasparjan, S.), 5, 13

Katayama, S., 13, 16, 17, 20, $23,25,29,32,34,36,37,39$, $41,43,45$

Kato (Sano, M.), 37, 39, 41

Katterfeld, L., see Carr, J.

Katz, I., 28 n.

Kavanagh, J., 37

Ker, A. (Keim, L. A.), 8

Kerrigan, P., 50, 54

Kilbom, K., 5, 13, 23, 36, 37, 39,41

Klinger, G. K., 1, 1 n.

Knorin, V. G., 43, 44, 45, 46, 47,48

Kobeckij, M. V., 2, 3, 4, 5

Köhler, B., 45, 47, 49, 51, 53, 55

Koenen, W., 4, 8

Koenig, A., 24
Kolarov, V., 16, 17, 18, 19, 20, Lozovskij, A. A. (Dridzo, S. $21,22,23,25,29,32,34,36$, $37,39,41,43,45,47,49,51$, $53,55,57$

Kon, F. Ja., 11, 15, 24, 38

Kon Sin (Kang Sheng), 49, 51, Macavei, M., 16 53,55

MacIlhon, 47

Koplenig, J., 37, 43, 45, 47, 49, MacManus, A., 16, 17, 20, 22, $51,53,55,57$

Koritschoner, F., 5, 13 $23,25,26,27,28$

Maffi, F., 23

Kornblum, I. R., 28 n., 30, 31 Maggi (Gennari, E., see also Krajewski, A. (Stein, W.), 50

Kreibich, K., 5, 9, 24 sub voce) $, 32,34,35,36,38$, 50,54

Królikowski, S., see Gliński, P. Malaka, T., 37

Kruminš, J., 49

Manner, K., 2, 13, 37

Kun, B., 4, 6, 23, 23 n., 27, 28, Manuil'skij, D. Z., 23, 25, 29, $32,34,36,37,39,41,43,45$, 47, 49

Kuusinen, O. W., 7, 9, 10, $11,12,13,14,15,16,17,18,19$, $20,21,22,23,25,26,27,28$, 28 n., 29, 30, 31, 32, 33, 34, $35,36,37,39,40,41,42,43$, $44,45,46,47,48,49,51,52$, $53,55,56,57$

Lacerda, F., see Ledo, A.

Ładan, P., see Niedobytyj

Larkin, J., 23

Larsen, A., see Lauersen

Lauer, H., see Brand, E.

Lauersen (Larsen, A.), 24

Lé Hông Phong, see Chayen

Ledo, A. (Lacerda, F.), 37, 41

Lehtinen, I., 57

Leiciague, L., 12, 12 n., 13

Lékai, J., 5 $31,32,33,34,35,36,37,39$, $40,41,42,43,44,45,46,47$, $48,49,51,52,53,55,56,56$ n., 57

Mao Tse-tung, 49, 53

Marchlewski, J., 1

Marco (Scoccimarro, M., see also $s u b$ voce), $23 \mathrm{n}$.

Maring (Sneevliet, H. J.F.M.), $2,2 \mathrm{n}$.

Marinović (Kaclerović, T., see also $s u b$ voce), $23 \mathrm{n}$.

Marković, S., 5, 13, 23, 39 n.

Marty, A., 49, 51, 52, 53, 55, 56,57

Maslow, A. (Čemerinskij, I.), 23

Men'šoj, A. G. (Levin, L. S.), $1 \mathrm{n}$.

Merino-Gracia, R., 5, 13

Meyer, E., 2, 2 n., 3, 4

Lenin, V. I. (Ul'janov, V. I.), Michal (Wolf, M.), 49, 51, 53, $2,5,13,16$ $55,55 \mathrm{n}$.

Leński, J. (Leszczyński, J.), Mickiewicz-Kapsukas, V., 23, $37,39,41,43,44,45,46,47, \quad 27,28,37$

$48,49,51$

Mikaeljan, see Sultan-Zade, A.

Leszczyński, J., see Leński, J. Milkić, I., 1, 2

Levi, P. 2, 2 n.

Levin, L. S., see Men'šoj, A. G.

Lévy, G., 17, $17 \mathrm{n}$.

Milković (Sakun, V.), 39, 39 n., 41

Minkin, A. E., 15

Li-Kuang (Su Chao-cheng), 37 Minor, R., 50, 54

Linderot, S., 49, 51, 53, 55

Mojrova, V. A., 37

Lipec, D., see Bennett, A. J.

Molotov, V. M. (Skrjabin, V. M.), 32, 33, 34, 35, 36, 37, 39, $40,41,42$ 1

Ljubarskij, N. M., see Carlo

Mondok, I., 38, $38 \mathrm{n}$.

Monmousseau, G., 37, 50, 54

Montagnana, M., see Roncoli

Moscovici, G., see Badulescu

Moskvin, M. A. (Trilisser, M, A.) $49,51,52$

Lominadze, V. V., 29

Longo, L., see Gallo, L.

Lopez, 37

Lovestone, J., 37, $41 \mathrm{n}$.

Lovickij (Popov, N. N.), 37, Miiller, K., 43 $37 \mathrm{n}$.

Münzenberg, W., 5 
Muna, A., 16, 23, 25

Murphy, J. T., 24, 32, 33, 34, Purman, L., 36, 37, 39, 41 36

Musabekov, G.-F., 5, 13

Musso, 37, 39, 41

\section{Naoradji, 37}

Nedjalkov, I., see Sablin, $N$.

Neumann, H., 43

Neurath, A., 13, 16, 17, 17 n., 18 n., 19, 20, 20 n., 21, 23, $25,26,28 \mathrm{n}$.

Newbold, J. T. W., 16

Niedobytyj (Ładan, P.), 23

No Kao Tsi-li, see Tu Ho-sin

Nosako, S., see Okano, S.

Okano, S. (Nosako, S.), 47, 49, $51,53,55$

Overstraeten, E. van, 5,13

Pak (Pak Chin-sun), 2

Pascal, 37

Paszyn, J., see Bielewski

Pauker, A., 57

Pauker, M., see Popescu

Pavlovič, M. L. (Vel'tmann, M. L.), 2, $2 \mathrm{n}$.

Penelon, J. F, 13, 23

Pepper, J. (Pogány, J.), 30, 30 n., 31

Pereira, A., see Astrogildo

Pérez Solis, O., see Persolis

Persolis (Pérez Solis, O.), 23

Petrov (Raskol'nikov, F. F.), 23, 23 n., 27, 28, 30, 31

Pieck, W., 37, 43, 44, 45, 46, $47,48,49,51,52,53,55,56$, 57

Pjatnickij, O. A. (Taršis, I. A.), $18,19,21,22,23,26$, $27,28,28$ п., 30, 31, 32, 33, $34,35,36,37,39,40,41,42$, $43,44,45,46,47,48$

Po Ku (Chin Pang-hsien), 49, 53

Pögelmann, H., 5, 13, 24

Pogány, J., see Pepper, J.

Pollitt, H., 23, 25, 25 n., 37, $39,41,43,44,45,46,47,48$, $49,51,53,55$

Popescu (Pauker, 1I.), 37

Popov, B., 49

Popov, D., 5

Popov, N. N., see Lovickij

Prestes, L. C., 49, 53

Prochniak, E., 13, 16, 24, 32, $34,36,37,39,41,43,45,47$, 49

Proost, J., see Jansen, J.

Quelch, Th., 2

Quierós, A. (Gonçalves, A.), 49,53 $16,17,20$ $19,21,49,53,57$

kakovskij, Ch., $1 \mathrm{n}$. 43, 44 53, 55

Reed, J., 2

Reiman, P. 37, 41 42,43

Riasco-Giulio, 37

Rienzi (Tasca, A.), 23, 25 sub voce), $23 \mathrm{n}$.

Rosenberg, A., 23

Rosso, 39, 41 35,36

Rust, W., 37, 39, 41 25, 25 n., 29

Rykov, A. I., 23, 25, 37 20,20 n., 32, 34, 36 $16,17,17$ n., 19

Salich, H., 13

Salim Abud, 49, 53

Samuelson, O., 23, 37

Sano, M., see Kato

Sar, 5,13

Sauki, 37

Schalker, C., 49, 53

Schlecht, P., 23, 25

Schneller, E., 37
Radek, K. (Sobelsohn, K.), 1 , 2,2 n., 4, 5, 6, 9, 12, 13, 14,

Rákosi, M., 7, 10,11, 15, 18 ,

Randolph (Weinstone, W. W., Sillen, H., 32, 34, 37, 43, 45, 47

see also $s u b$ voce), 41, $41 \mathrm{n}$,, Simić (Marković, S., see also

Raskol'nikov, F. F., see Petrov

Raymond (Guyot, R.), 49, 51,

Remmele, H., 29, 32, 33, 34, $35,36,37,39,40,40$ n., 41 ,

Robert (Maslow, A., see also

Roca, B. (Calderio, F.), 49, 53

Roncoli (Montagnana, M.), 47

Rosmer, A. (Griot, A.), 2, 4

Roy, M. N. (Bhattacharya, N. N.), 5,5 n., 13, 16, 23, 25, 25 n., 29, 30, 31, 32, 33, 34,

Rudnyánszky, E., 1 n., 2, 3, 4

Ruthenberg, Ch. E., 23, 23 n.,

Sablin, N. (Nedjalkov, I.), 2

Sackin, L. M., 2, 14, 16, 17 n.,

Safarov, G. I. (Egorov, G. I.),

Scheflo, O., 5, 13, 16, 23, 25

Schüller, R., 13, 16, 19, 20 n., Sumskij, A. Ja., 5, 13
22,23 n., 27, 28, 32, 34, 36

Scoccimarro, M., 23

Sellier, L., 9, 9 n., 23

Semaoen, 23, 32, 34, 36

. Sémard, P., 23, 25, 29, 29 n., $34,36,37,39,41$

Senander, K., 50, 54

Serra (Tasca, A.), 37, 39, 40

Serrati, G. M., 2

Shafik (Deymer, Sh. H.), 24

Shargi, 38

Sharkey, L., 49, 53

Shields, J., 45 sub voce), $23 \mathrm{n}$.

Siroký, V., 49, 53

Sirola, Y., 1, 1 n., 5, 8, 38, 50

Skirjatov, M. F., 50, 54

Skrypnik, N. A., 37

Smeral, B., 12, 12 n., 13, 14 n., $16,17,17$ n., 20 n., 23, 25, $29,30,31,32,33,33$ n., 34, $35,36,37,37$ n., $39,40,41$, $42,43,50,54$

Sneevliet, H. J. F. M., see Maring

Sochacki, J., see Bratkowski, J.

Sokolik (Knorin, V. G., see also sub voce), 37, $37 \mathrm{n}$.

Sokolnikov, G. Ja. (Brilliant, G. Ja.), 23 n., 25

Sol'c, A. A., 24, 38

Souvarine, B. (Lif̌sis, B.), 5, $6,9,9$ n., 12,12 n., 14, 16, $17,20,22$

Spector, M., 37, 41 n.

Stalin, I. V. (Džugašvili, I. V.) $2,23,25,29,32,34,36$, $37,39,41,43,45,47,49,51$, 53,55

Stasova, E. D., 50, 54

Stefanescu, 38

Stefanov, B., 49, 53

Steinhardt, K., 2

Stewart, R., 20 n., 22, 23

Stirner, A. (Woog, E.), 16, 24

Stoecker, W., 18, $18 \mathrm{n}$.

Stojnov (Dimitrov, S.), 49, 53

Strachov (Chï Chiu-pai), $40 \mathrm{n}$.

Stučka, P., 1, 2, 2 n., 5, 13, 24, 38

Su, 43, 45

Su Chao-cheng, see Li-Kuang

Su Fan (Chen Ho-sian?), 29

Sultan-Zade, A. (Mikaeljan), $2,5,13$ 
Sverma, J., 49, 53

Syphneios, 37

Tan-Pin (Tan Ping-shan), 32, 34

Tan Ping-shan, see Tan-Pin

Tasca, A., see Rienzi and Serra

Terracini, U., 5, 9, 20, $20 \mathrm{n}, 22$

Thälmann, E., 23, 25, 29, 29

n., $32,34,36,37,39,41,43$, $44,45,46,47,48,49,53$

Thögersen, Th., 37

Thomas (Reich, J.), $1 \mathrm{n}$.

Thorez, M., 37, 43, 44, 45, 46, Vaillant-Couturier, P., 8 $47,48,49,51,53,55,57$

Togliatti, P., see Ercoli Varga, J., 2 n., 37, 49, 53 Verčik, J., 23, 37

Tomskij, M. P. (Efremov, M. Vincenzi, 36 P.), 2 Visser, L. de, 37, 49, 53

Treint, A., 23, 25, 26, 27, 28, Vompe, P. A., 19, 19 n. $28 \mathrm{n} ., 29,31,32,34$

Vorovskij, V. V., 1, $1 \mathrm{n}$.

Trilisser, M. A., see Moskvin, Vujović, V., 23, 23 n., 25, 29 M. A.

Trockij, L. D. (Bronstein, L. Walecki, H. (Horwitz, M.), 8,
9,50

Wallenius, A., 13

Wang Ming (Chen Shao-yui), $45,46,47,48,49,51,52,53$, 55,56

Watanabe, M., see Asano

Weinstein, $36 \mathrm{n}$.

Weinstone, W. W., 38

Weiss, 38

Wieser, F., 37

Wijnkoop, D., 2, 23

Wolf, M., see Michal

Woog, E., see Stirner, A.

Zachariades, N., see Dimitriu Zápotocký, A., 23, 37, 49, 53 Ždanov, A. A., 49, 53, 57, 57 n. Zetkin, C., 8, 13, 16, 17, 20, 23, $25,26,26$ n., 29, 32, 34, 36, $37,39,41,43,45$

Zinov'ev, G. E. (Radomysl'skij, G. E.), 1,1 n., 2, 3, 4, 5, 6, 9, $12,13,14,16,17,20,23,25$, $29,32 \mathrm{n}$. 